\title{
Bioactive Compounds of Nutraceutical Value from Fishery and Aquaculture Discards
}

\author{
Mirko Mutalipassi ${ }^{1,+}+\mathbb{D}$, Roberta Esposito ${ }^{2,3,+}$, Nadia Ruocco ${ }^{2,+}$, Thomas Viel ${ }^{1}$, Maria Costantini ${ }^{2, *}$ \\ and Valerio Zupo ${ }^{1, *(1)}$ \\ 1 Stazione Zoologica Anton Dohrn, Department of Marine Biotechnology, Villa Dohrn, Punta San Pietro, \\ 80077 Naples, Italy; mirko.mutalipassi@szn.it (M.M.); thomas.viel7@gmail.com (T.V.) \\ 2 Stazione Zoologica Anton Dohrn, Department of Marine Biotechnology, Villa Comunale, 80121 Naples, Italy; \\ roberta.esposito@szn.it (R.E.); nadia.ruocco@szn.it (N.R.) \\ 3 Department of Biology, University of Naples Federico II, Complesso Universitario di Monte Sant'Angelo, \\ Via Cinthia 21, 80126 Naples, Italy \\ * Correspondence: maria.costantini@szn.it (M.C.); valerio.zupo@szn.it (V.Z.) \\ + These authors contributed equally to this work.
}

Citation: Mutalipassi, M.; Esposito, R.; Ruocco, N.; Viel, T.; Costantini, M.; Zupo, V. Bioactive Compounds of Nutraceutical Value from Fishery and Aquaculture Discards. Foods 2021, 10, 1495. https://doi.org/10.3390/foods 10071495

Academic Editors: Ermelinda Prato and Francesca Biandolino

Received: 13 May 2021

Accepted: 25 June 2021

Published: 28 June 2021

Publisher's Note: MDPI stays neutral with regard to jurisdictional claims in published maps and institutional affiliations.

Copyright: (c) 2021 by the authors. Licensee MDPI, Basel, Switzerland. This article is an open access article distributed under the terms and conditions of the Creative Commons Attribution (CC BY) license (https:/ / creativecommons.org/licenses/by/ $4.0 /)$.

\begin{abstract}
Seafood by-products, produced by a range of different organisms, such as fishes, shellfishes, squids, and bivalves, are usually discarded as wastes, despite their possible use for innovative formulations of functional foods. Considering that "wastes" of industrial processing represent up to $75 \%$ of the whole organisms, the loss of profit may be coupled with the loss of ecological sustainability, due to the scarce recycling of natural resources. Fish head, viscera, skin, bones, scales, as well as exoskeletons, pens, ink, and clam shells can be considered as useful wastes, in various weight percentages, according to the considered species and taxa. Besides several protein sources, still underexploited, the most interesting applications of fisheries and aquaculture by-products are foreseen in the biotechnological field. In fact, by-products obtained from marine sources may supply bioactive molecules, such as collagen, peptides, polyunsaturated fatty acids, antioxidant compounds, and chitin, as well as catalysts in biodiesel synthesis. In addition, those sources can be processed via chemical procedures, enzymatic and fermentation technologies, and chemical modifications, to obtain compounds with antioxidant, anti-microbial, anti-cancer, anti-hypertensive, anti-diabetic, and anti-coagulant effects. Here, we review the main discards from fishery and aquaculture practices and analyse several bioactive compounds isolated from seafood by-products. In particular, we focus on the possible valorisation of seafood and their by-products, which represent a source of biomolecules, useful for the sustainable production of high-value nutraceutical compounds in our circular economy era.
\end{abstract}

Keywords: wastes; seafood; aquaculture; fishery; functional foods; bioactive compounds; biotechnology; sustainability

\section{Introduction \\ 1.1. Fishery/Aquaculture Practices and Targeted Organisms}

Global seafood production in the year 2016 was assessed to be about 171 million tons (Figure 1) [1]. Fishery activities and aquaculture generate a wide array of different wastes. First of all, plastic wastes are heavily produced due to abandoned, lost or discarded fishing gear bilges, as well as other wastes from vessel operations. In parallel, fisheries bycatch discards are produced through low-selective fishing gears, not equipped to exclude non-targeted organisms. These latter methods may catch significant amounts of finfish species, juveniles, benthic animals, marine mammals, marine birds and vulnerable or endangered species, which are often immediately discarded. Moreover, unmarketable organisms due to small size, as well as damaged and inedible specimens, cannot be retained due to management or quota restrictions [2]. 


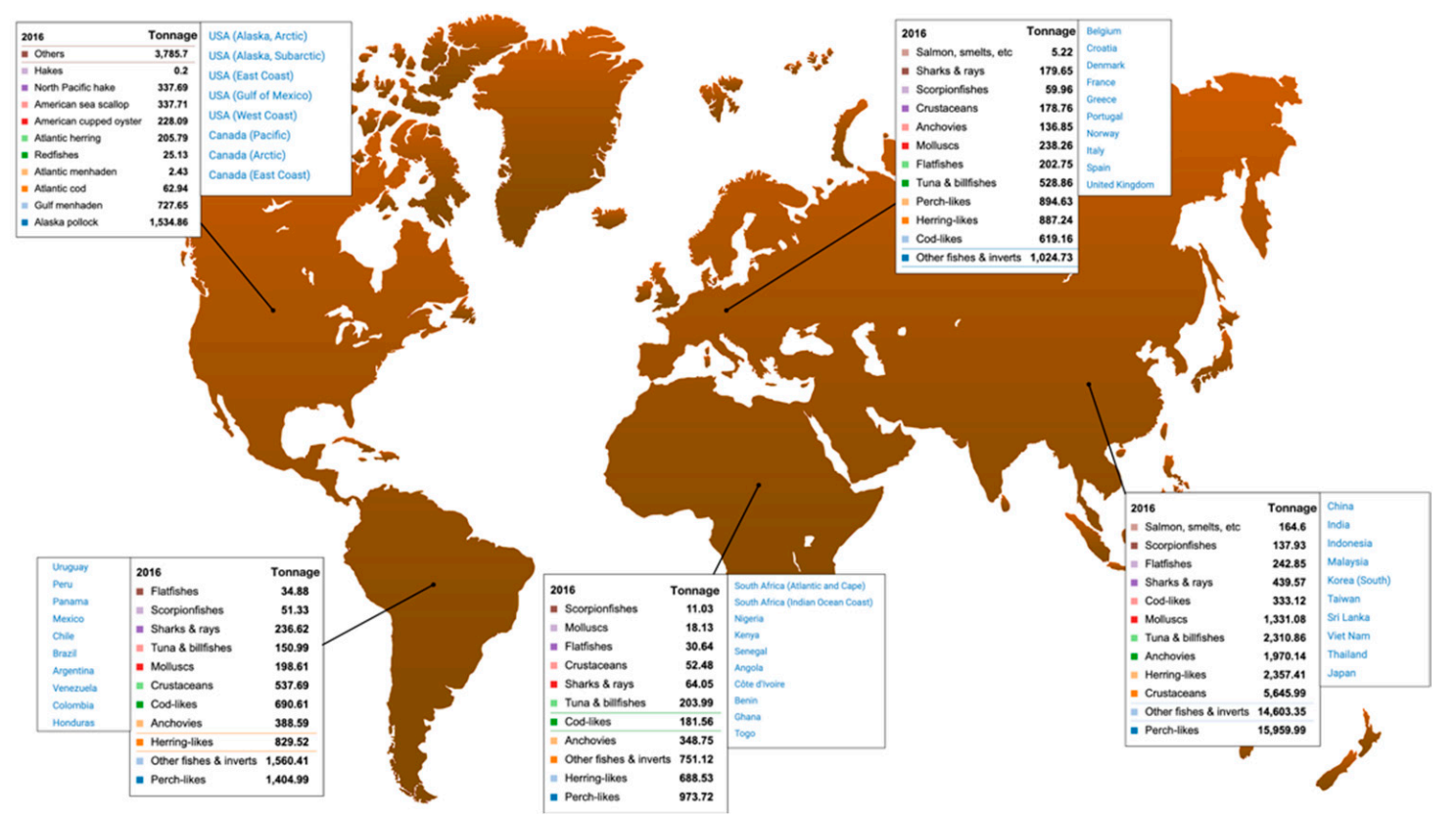

Figure 1. Global seafood production (updated in 2016) according to Pauly et al. [1].

Within fisheries management, discarding is currently one of the most important issues, both from the economic and the environmental point of view [3]. The Food and Agriculture Organization (FAO) Fisheries Glossary describes it as "that proportion of the total organic material of animal origin in the catch which is thrown away or dumped at sea, for whatever reason. It does not include plant materials and postharvest wastes such as offal. The discards may be dead or alive". In the United States, during the period 2009-2013, about $47 \%$ of the edible seafood was not used for human consumption, representing a large percentage of harvest discarded as by-catch during commercial fishing [4]. A comparable situation was found in Europe, where the ratio between seafood consumed and discarded as waste is estimated to be 1:1 [5]. Scientists and fishery managers underlined the importance of reducing these wastes, minimizing the ecological impacts of fishery [6-12]. In addition, a strong diversification of marine harvest was recommended, to reduce the fishing pressure on current target species by using those that are not considered interesting for commercial purposes [12].

Active bottom-contact gears (e.g., bottom trawls) are widespread large-scale fishing techniques, generally known to produce the highest discarding as compared to any other fishing gear which in many countries are becoming a real concern [2]. Thus, shrimp fisheries, particularly in tropical waters, had the highest total amount and proportion of discards with a weighted average rate of $62 \%$ [2,13-15]. Shrimp trawling produces the highest level of discard/catch rations if compared with other fishing techniques with values ranging from 3:1 to 15:1, according to target species, seasons and areas [16]. Along the Indian coasts, fishery bycatch is mainly composed of high proportions of juveniles and sub-adult individuals of commercially important species. It was estimated that in 2008 the annual economic loss due to juveniles in fishing, by trawlers, purse seiners, ring seiners and mini-trawlers together, was about US\$ 19.445 million $\mathrm{yr}^{-1}$ [17]. If compared to shrimp fisheries, finfish trawling has a relatively low discard rate, contributing to a substantial total amount of discards worldwide. In addition, tuna and high migratory species contribute to total bycatch with up to $28.5 \%$ of the weighted average discard rate. In contrast, small-scale and artisanal fisheries exhibit very low or negligible discards, although in some areas, for example in the Mediterranean, the total amount of discards can still be very substantial due to a huge presence of artisanal fleets [18,19].

The taxonomic composition of discards varies among different areas and techniques according to the natural biodiversity patterns of fishing areas, target taxa, fisheries types, and 
gears. In the Atlantic Ocean, redfish (Sebastidae, 19\%), hake (Merlucciidae, 18\%), American plaice (Pleuronectidae, 13\%) and rays (Rajidae, 12\%) are the dominating species [2]. These organisms are potentially marketable but, when taken by fishing gears, are not retained and utilized, either because of poor product quality or small size and/or due to deliberate high-grading of catches (especially in areas outside of management intervention). In the northeast Atlantic Ocean, discarded species are quite different ranging from haddock (Gadidae, 19\%), redfish (16\%), Atlantic cod (Gadidae, 11\%) and hake (6\%). Data from eastern central Atlantic area (west Africa, FAO area 34) show a lack of resolution but it is possible to identify some taxonomically distinct entities, such as cephalopods (Cephalopoda, 4\%), followed by small pelagic species (European anchovy, Engraulidae) and the European pilchard (Clupeidae). An important number of discards are "miscellaneous marine organisms", both for pelagic and coastal fisheries, which account for up to $24 \%$ of the total discarded animals that are generally non-marketable species, such as starfish (Asteroidea, 6\%) and sharks (e.g., Prionace glauca, Carcharhinidae) [2].

In addition to other bycatch species, jellyfish are interesting cases of study [20], since they are usually avoided by fishermen for their capability to interfere with fishing activities [21]. The occurrence of high-density gelatinous organisms during blooms are correlated with both favourable conditions in marine environments and intrinsic biological characteristics of each group [22]. In Brazil, jellyfish are identified as the organisms caught in the highest frequency and number, especially during spring and summer as in the case of the hydromedusa Rhacostoma atlanticum. Potential uses of jellyfish for commercial purposes are still in early stages although some studies were conducted to capture and process these organisms for human consumption. In fact, in some Asian countries, jellyfish are considered a delicacy and their commercial market is increasing [20]. In addition to this potential utilization, jellyfish are extremely rich in secondary metabolites that could find interesting applications in biotechnological fields [23]. Recently, a commercial product named Prevagen ${ }^{\circledR}$, a dietary supplement containing apoaequorin, a protein extracted from the jellyfish Aequorea victoria, has been demonstrated to bind calcium in the brain, improving the electrical signals between nerve cells and contributing to prevent dementia and Alzheimer's disease [24,25].

\subsection{Most Useful Discards from Several Seafood Taxa}

Seafood wastes are used as raw material for silage, fish meal, and fertilizer or as a component of aqua- and poultry feeds [26-29] thank to the high content of proteins, polyunsaturated fatty acids (PUFA), and other nutrients having various health benefits including carotenoids, minerals, vitamins, squalene, glycosaminoglycans. For this reason, despite the low value traditionally assigned to fishery by-products, there is a growing interest in the potential use of these wastes as functional ingredients, nutraceuticals, and pharmaceuticals in a wide range of applications [30-37]. On one side, this approach offers a significant benefit from an economical point of view, providing additional income from a material that, in some cases, has a disposal cost. On the other side, the valorization of seafood wastes, including bycatch and byproduct, can strongly reduce environmental pollution [38]. Since fishery and aquaculture wastes are rich in high-quality nutrients, there is a great potential in the marine bioprocess industry to convert and use a large fraction of these valuable products. For instance, seafood represent a rich source of proteins varying in functional and biological properties [26,39], available in high concentration in fish heads, backbones, tails etc. These proteins, as well as other biomolecules retrieved in seafood and especially in shellfish, can be easily extracted using new technologies developed for biotechnological purposes, as in the case of the chitosan produced from exoskeletons of the shrimp Pleoticus muelleri $[40,41]$. These advances include (a) macromolecules biotransformation via enzymes or microorganisms, (b) subcritical and supercritical extractions for the isolation of target products, (c) ultra-filtration, (d) microwave and (e) ultrasound-assisted recovery processes and membrane separation $[37,39,42,43]$. For these reasons, cheap and 
energy-efficient enzymatic techniques are emerging in food processing, based on the use of proteases, glycoside hydrolases, lipases, and transglutaminases [44,45].

The pre-processing operations of seafood, from fisheries and aquaculture, generate miscellaneous wastes, depending on the raw material and the desired final products in diverse markets [46,47]. Seafood processing wastes include beheading, de-shelling, skinning, gutting, removal of fins and scales, filleting, washing, etc. This waste can represent up to $40 \%$ of the total seafood. This material can be wasted as solid discards, offal, or by-product [33]. The percentage of waste materials can vary according to the processed organism, as in the case of finfish, generating up to $50 \%$ of waste material that comprises entrails, heads, skeletal frames, skin, scales, and viscera. The same wastes are produced during tuna canning operations but the process, in this case, results in a higher percentage of solid wastes (about 70\%).

Crustacean wastes and byproducts can reach $75 \%$ of the shellfish, as in the case of lobster processing industries, which are composed of cephalothorax, carapace, tail, and shell [30-33,48]. Shellfish wastes are largely insoluble and very resistant to natural biodegradation, which might lead to health and environmental concerns. However, the constituents of shells, generally $30 \%$ protein and $30 \%$ chitin, make them interesting for further processing. A major problem with shrimp biomaterial valorization is the high perishability of the material that, in a tropical climate, is rapidly deteriorated by bacterial activities. Various technologies have been developed to use shrimp wastes, replace standard and hazardous chemical methods and extract bioactive compounds [49]. Shellfish are rich in carotenoids, which are lipophilic compounds responsible for yellow and red colours in nature [50] and, in particular, astaxanthin is commercially exploited due to its role as antioxidant, and in aquaculture as a feed additive for enhancing flesh colouration (i.e., the pink colour) of farmed salmonids which is generally desired by consumers [37,51,52].

In addition to fishes and crustaceans, marine algae wastes can be potentially exploited. In fact, from a nutritional point of view, edible seaweeds are rich in minerals and vitamins, being recognized as an ideal source of iodine as well as one of the few plant sources of vitamin B12 [53]. Various seaweeds have been historically harvested for human consumption and Ulva (Chlorophyta), Porphyra (Rhodophyta), Undaria, Laminaria, Himanthalia, and Saccharina (Phaeophyceae) are common ingredients of many Asian recipes [54], improving the quality of various food products [55]. Macroalgae wastes are not sufficient to satisfy worldwide demand and several algal species are intensively cultivated, especially in integrated aquacultures [56,57].

\subsection{Aim of the Review}

In the present review, we considered the studies describing the seafood-derived compounds with potential use in nutraceutical field (see Tables 1-7). Several classes of compounds were chosen, including collagen, gelatin, minerals, proteins, lipids, carotenoids, polysaccharides, and phenols. For each of them, we outlined which taxa, organism or, tissue, might be the most interesting source. When available, we highlighted the bioactivity of these compounds, demonstrated through in vitro or in vivo tests, such as antioxidant, anti-hypertensive, anti-diabetes and so on. We finally reported some examples of commercialized products containing seafood-derived compounds already used for treating human diseases. The biotechnological significance of aquaculture, fishing, and industrial by-products was thus investigated and debated, together with future expectations and challenges.

\section{Collagen and Gelatin}

Collagen type I, II, and IV have been particularly extracted from skin, bones, scales and cartilages [58], through a sustainable approach respecting the European zero-waste strategy. In fact, fish, echinoderms and jellyfish discards are suitable sources of high-quality collagen that has been efficiently extracted and processed by acid, alkaline, and enzymatic treatments coupled to mechanical methods, such as $\mathrm{pH}$ adjustments, homogenization, 
and sonication [59]. Type I collagen was extracted from the tissue of sea urchins [60,61], octopus [62], starfish [63], jellyfish [63], and several species of fish [64-66]. The main amino acids found within collagen and gelatin molecules are glycine (Gly), alanine (Ala), proline (Pro) and hydroxyproline, with basically a Gly-X-Y triplet as a repeating unit. Amino acids composition may differ depending on the environmental conditions (e.g., temperature), type of tissue, and extraction methods [67].

Nowadays, collagen displayed a wide range of applications in the health-related sectors, namely in cosmetics, the pharmaceutical industry and medical care (including plastic surgery, orthopaedics, ophthalmology and dentistry) [68]. Despite the high potentialities of collagen and gelatin for developing medical products and new therapeutic strategies, so far, only a few examples of commercially available drugs have been recorded [69]. Concerning non-health sectors, a noteworthy use of collagen is related to the food sector (food processing and nutraceuticals), but most often as gelatin, i.e., in its denatured form [36]. Indeed, collagen has become a functional ingredient towards the "healthy foods" development. Generally, collagen production decreases with age and bad diet [70] and consequently food supplements are intended to uphold the skin, hair, nails, and body tissues of the users [71]. Fish gelatin can be obtained by hydrolyzing and denaturing collagen [72] through a pre-treatment step, which is necessary before the extraction for improving the extraction efficiency. The pre-treatment consists of acid or alkaline hydrolysis, a method chosen according to the source material [72], and gelatin can be prepared by acid or water extraction [73]. The properties of gelatin are influenced by two main factors: the characteristics of the initial collagen and the extraction process [73,74]. Gelatin is widely used as an ingredient to improve the elasticity, texture and stability of foods but it may also give rise to biologically active peptides by protease hydrolysis. These metabolites have a potential activity as inhibitors of angiotensin I converting enzyme (ACE) or as antioxidants. For instance, gelatin obtained by acid extraction from four different species of local marine fish caught off the coast of Langkawi Island, Malaysia, such as "kerapu" (Epinephelus sexfasciatus), "jenahak" (Lutjianus argentimaculatus), "kembung" (Rastrelliger kanagurta), and "kerisi" (Pristipomodes typus) contained essential amino acids, with glycine being the most predominant (Table 1) [75]. Gelatin extracted from tunafish and giant squid tunics (Dosidicus gigas) demonstrated antioxidant activity after hydrolysis with trypsin, $\alpha$ chymotrypsin or pepsin [76]. This work confirmed the high antioxidant capacity of whole and fractionated alcalase hydrolysates of gelatin from giant squids. This capacity was noticeably higher than that obtained from tuna fish, under the same hydrolysis conditions [76]. In a similar study, the antioxidant activities of gelatins extracted from frozen inner and outer tunics of the jumbo flying squid (Dosidicus gigas), tuna (Thunnus spp.) and halibut (Hypoglossus spp.) skins were evaluated by FRAP (ferric reducing antioxidant power) and ABTS (2,2'-azino-bis-3-ethylbenzothiazoline-6-sulfonic acid) assays [77]. In particular, gelatin extracted from squid showed a greater antioxidant activity due to the reduction of iron and an enhancement of the removal of free radicals [77]. Peptides purified from skin gelatin of the Pacific cod (Gadus macrocephalus), in particular papain hydrolysate, showed potent antioxidant activity [78]. Furthermore, the peptides obtained from the purification of papain hydrolysate showed a potential inhibitory effect of the ACE enzyme [78]. The gelatin extracted from the skin of the Chum Salmon (Oncorhynchus keta) and its hydrolysate had protective effects against UV irradiation-induced skin photoaging [79]. In particular, gelatin hydrolysate of the salmon skin could be used in the nutraceutical and cosmeceutical industries to reduce oxidative stress, maintain the homeostasis of the collagen matrix [80], and strengthen the immune system [81].

Ultrasound treatment for the extraction of collagen from the skin of the sea bass Lateolabrax japonicus has been developed by several authors [82]. In addition, collagen extracted by giant edible jellyfish, Nemopilema nomurai, stimulated the production of immunoglobulins and cytokines by human hybridoma cells and human peripheral blood lymphocytes without inducing allergic complications [83]. 
Table 1. Gelatin and collagen from seafood wastes, together with taxa, species and tissue from which they were isolated, and their biotechnological application. N/A refers to "not applicable".

\begin{tabular}{|c|c|c|c|c|c|}
\hline Taxa & Species & Tissue & Product & Biological Activity & Reference \\
\hline Fish & $\begin{array}{l}\text { Epinephelus sexfasciatu, Lutjianus } \\
\text { argentimaculatus, Rastrelliger } \\
\text { kanagurta, Pristipomodes typus }\end{array}$ & $\mathrm{N} / \mathrm{A}$ & Gelatin & $\mathrm{N} / \mathrm{A}$ & [75] \\
\hline Bivalve & Dosidicus gigas & Tunics & Gelatin & Antioxidant & [76] \\
\hline Bivalve and fish & $\begin{array}{c}\text { Dosidicus giga, Thunnus spp., } \\
\text { Hypoglossus spp. }\end{array}$ & $\begin{array}{l}\text { Inner and } \\
\text { outer tunics }\end{array}$ & Gelatin & Antioxidant & [77] \\
\hline Fish & Gadus macrocephalus & Skin & Gelatin & Antioxidant & [78] \\
\hline Fish & Lateolabrax japonicus & Skin & Collagen & $\mathrm{N} / \mathrm{A}$ & [82] \\
\hline Fish & Oncorhynchus keta & Skin & Gelatin & Antioxidant & [79] \\
\hline Jellyfish & Nemopilema nomurai & Body & Collagen & Antioxidant & [83] \\
\hline
\end{tabular}

\section{Mineral Salts}

These compounds are divided into the major minerals (macro-minerals), such as calcium, sodium and potassium, and trace minerals (micro-minerals), including iron, copper, zinc, and manganese (Table 2) [84].

Among them, calcium is a fundamental element for the physiology of vertebrates, to build and maintain strong bones, as well as for many other tissues and biochemical processes [85]. Calcium extracted from food wastes showed good potentialities to make calcium-enriched bread for treating patients with osteoporosis deficiencies [86]. As demonstrated by Jung et al. [87], the skeletons discarded from industrial processing of hoki (Johnius belengerii) and its digested products could be used as nutraceuticals with potential calcium-binding activity. Milk tablets supplemented with nano-powdered eggshell (NPES) or nano-powdered oyster shell (NPOS), NPES with zinc (Zn-NPES), and NPOS with activated zinc (Zn-NPOS) were found suitable tools for calcium supply since did not show any significant differences in $\mathrm{pH}$, consistency, colour, humidity when compared to control milk tablets [88]. Moreover, bread enriched with oyster shells showed higher protein, ash and fiber contents than control bread. In addition, the eggshell and oyster bread had significantly higher levels of calcium, iron, zinc, and phosphorus than the control. The fortification of bread with natural sources of calcium, such as skimmed milk powder and waste products, like oyster shell and eggshell powders, was demonstrated to improve the rheological characteristics of dough and the quality and nutritional properties compared to the control bread [89]. Although some studies investigated the high value of calcium from seafood by-products as food supplement, it must be considered that solubilization and ionization processes are necessary for its real adsorption. This latter issue raises not a few limits to a concrete application of marine calcium minerals for human consumption [90].

Iron is another mineral involved in many biochemical processes such as oxygen transport, energy production and cell proliferation [91] and for these reasons is one of the most important trace minerals in human physiology. However, nearly one-fifth of the population in the world reports some nutrition issues due to iron deficiency [92,93]. Therefore, iron can be administered through the diet in salts, metal chelating agents and iron-chelating peptides. For instance, the skin of the Alaska pollock hydrolyzed with trypsin generates iron-chelating peptides of high stability and adsorption features useful as iron vehicles in therapeutic food supplements [94].

Marine seaweeds contain 10-100 times more minerals than traditional vegetables with iron, copper, calcium, and magnesium present in higher concentrations [95]. Moreover, seaweeds can be considered as the best inexpensive food to fulfil the iodine requirements of humans and, more generally, they can be used as mineral food supplement [96], as well as, for their beneficial effect on hypercholesterolemia and arterial hypertension [97]. Due to their nutritional value, algae are commonly used as dietary supplements, as in the case of algae belonging to the Spirulina and Chlorella genera [55]. For example, Laminaria japonica 
is known to store marine minerals in a highly concentrated form, and it has been used to produce algae-based ingredients for skin protection against UV damage [98].

Table 2. Minerals and peptides carrying minerals from seafood wastes, together with taxa, species and tissue from which they were isolated, and their biotechnological application.

\begin{tabular}{|c|c|c|c|c|c|}
\hline Taxa & Species & Tissue & Product & $\begin{array}{c}\text { Biological Activity/ } \\
\text { Nutraceutical Application }\end{array}$ & Reference \\
\hline Fish & $\begin{array}{l}\text { Johnius belengerii, } \\
\text { Thunnus thynnus }\end{array}$ & Skeletons & Phosphopeptide & $\begin{array}{l}\text { Potential calcium-binding } \\
\text { activity/food supply }\end{array}$ & [87] \\
\hline Bivalve & $\mathrm{N} / \mathrm{A}$ & Shell & Calcium & Food supplement & [88] \\
\hline Bivalve & $\mathrm{N} / \mathrm{A}$ & Shell & $\begin{array}{l}\text { Calcium, iron, zinc } \\
\text { and phosphorus }\end{array}$ & Food supplement & [89] \\
\hline Fish & $\begin{array}{c}\text { Gadus } \\
\text { chalcogrammus }\end{array}$ & Skin & Peptides & $\begin{array}{l}\text { Iron-chelating/food } \\
\text { supply }\end{array}$ & [94] \\
\hline Brown alga & Laminaria japonica & NA & Minerals & Antioxidant & [98] \\
\hline
\end{tabular}

\section{Protein and Protein Hydrolysates}

Despite the availability on the market of various molecules with anti-hypertensive activity, clinical tests indicate that side effects, such as cough and angioedema, are extremely common [99]. A potential solution is to replace the synthetic inhibitors, normally used in therapeutic formulation, with natural peptides retrieved in food proteins [100]. Interestingly, marine bioactive peptides possess various biological functions, including the inhibition of ACE, antioxidant, immunomodulatory, anti-microbial, and anti-coagulant activities (Table 3) [101,102]. Fish protein hydrolysates, for their amino acid composition and easily digestible proteins, are considered to have excellent quality, from a nutritional point of view. Nevertheless, due to the unpleasant fishy smell and flavour, they were mostly used for animal nutrition $[103,104]$. Recent studies provided evidence that marine bioactive peptides from several marine organisms act as potential antioxidant inhibiting lipid peroxidation and removing reactive oxygen species [105,106]. Interestingly, free radicals scavenging activity has been addressed to the hydrophobic amino acids (e.g., alanine, phenylalanine, isoleucine, leucine, valine and glycine and proline, methionine, tyrosine, histidine, lysine and cysteine) that may improve the efficiency of antioxidant peptides. In fact, these amino acids could act as proton donors or electron and/or as lipid radical scavengers [107]. For instance, His-Gly-Pro-Leu-Gly-Pro-Leu (797 Da) peptides extracted from fish Hoki (Johnius belengerii) skin gelatin had antioxidant activity, tested in a linoleic acid peroxidation system and radical-scavenging potency. In addition, antioxidative enzyme levels in cultured human hepatoma cells increased in the presence of this peptide, suggesting that it was involved in maintaining the redox balance in the cell environment [108]. Alkalin-pretreated cobia (Rachycentron canadum) skin was extracted in a retort for $30 \mathrm{~min}$ to obtain a retorted skin gelatin hydrolysate (RSGH). Cobia RSGH and its derivatives showed a strong antioxidant activity by inhibiting lipid peroxidation. It is well-known that lipid peroxidation occurring in food products deteriorates food quality, resulting in rancidity, unacceptable taste, and shorter shelf-life. The RSGH retarded lipid deterioration and may be used as a natural antioxidant for food products. In fact, these peptides can be used as antioxidants in functional foods and supplements [109]. In another study, antioxidant activity of fish protein hydrolysates obtained from cod backbones (Gadus morhua) was evaluated using liposomes and DPPH (2,2-diphenyl-1-picrylhydrazyl) radical scavenging assay. Moreover, the DPPH scavenging activity showed that the anti-oxidative activity of hydrolysates could be due to the ability to scavenge lipid radicals [110]. The protein hydrolysates obtained through different enzymatic treatments from sardine heads and/or entrails (Sardinella aurita) [111,112], Alaska pollack (Theragra chalcogramma) skin [113], and from the muscles of the sea bream (Nemipterus japonicus) and other fish (Exocoetus volitans) showed antioxidant activity. Moreover, the trypsin protein hydrolysates of both fishes showed maximum free radical scavenging potential and lipid peroxidation inhibi- 
tion. Furthermore, these peptides showed a significant anti-proliferative effect on Hep G2 (human hepatocellular liver carcinoma) cell line [114]. A peptide was isolated from the Black pomfret (Parastromateus niger) viscera, showing a peculiar antioxidant activity, able to inhibit lipid peroxidation and oxidative damage [115]. A similar activity was also identified in Horse mackerel visceral protein hydrolysate from the fish Magalaspis cordyla. In particular, this peptide inhibited lipid peroxidation avoiding oxidative damage in living systems [116]. In vitro assays reported antioxidant activities in two peptides isolated from skin protein hydrolysates of the horse mackerel (Magalaspis cordyla) and the croaker (Otolithes ruber) [117,118], and eight hydrolysates from cuttlefish (Sepia officinalis) by-products (skin and viscera) obtained through treatment with various gastrointestinal proteases (chymotrypsin, trypsin, and crude alkaline enzyme and bacterial proteases) [119]. As reported for the antioxidant properties, ACE inhibitory activity was also attributed to the differences in chain length and amino acids sequences of peptides, as well as, to their hydrophobicity [120]. For instance, an ACE inhibitory Gly-Leu-Pro-Leu-Asn-Leu-Pro (M.W. $770 \mathrm{Da}$ ) hydrophobic peptide isolated from salmon skin (Oncorhynchus keta) was found to reduce systolic blood pressure after oral administration in rats, suggesting a possible use of this peptide as a functional food with anti-hypertensive effect [121]. Moreover, the jellyfish aqueous/hydroalcoholic extracts and the hydrolyzed peptides resulting from pepsin and collagenase digestions obtained from three Mediterranean species of jellyfish (Aurelia sp., Cotylorhiza tuberculate, and Rhizostoma pulmo) showed evident antioxidant activity, with suitable application in nutraceutical, cosmeceutical, and pharmacological fields [122]. Antioxidant and ACE inhibitory molecules can be found in other jellyfishes, as in the case of Rhopilema esculentus Kishinouye, where a Ser-Tyr dipeptide abundant in the gonads of this species, had DPPH, hydroxyl and superoxide radical scavenging effects with $\mathrm{IC}_{50} 84.623 \mu \mathrm{M}, 1177.632 \mu \mathrm{M}, 456.663 \mu \mathrm{M}$, respectively [123,124].

Table 3. Proteins and protein hydrolysates from seafood wastes, together with the taxa, species and tissue from which they were isolated, and their biotechnological application.

\begin{tabular}{|c|c|c|c|c|c|}
\hline Taxa & Species & Tissue & Product & Biological Activity & Reference \\
\hline Fish & Johnius belengeri & Skin & Peptides & Antioxidant & [108] \\
\hline Fish & Rachycentron canadum & Skin & Gelatin derivate & Antioxidant & [109] \\
\hline Fish & Gadus morhua & Backbones & Protein hydrolysates & Antioxidant & [110] \\
\hline Fish & Sardinella aurita & $\begin{array}{l}\text { Heads and/ } \\
\text { or entrails }\end{array}$ & Protein hydrolysates & Antioxidant & {$[111,112]$} \\
\hline Fish & Theragra chalcogramma & Skin & Peptides & Antioxidant & [113] \\
\hline Fish & Nemipterus japonicus & Muscles & $\begin{array}{l}\text { Hydrolysates and } \\
\text { peptide fractions }\end{array}$ & Antioxidant & [114] \\
\hline Fish & Exocoetus volitans & Muscles & $\begin{array}{l}\text { Hydrolysates and } \\
\text { peptide fractions }\end{array}$ & $\begin{array}{l}\text { Antioxidant } \\
\text { and anti-tumor }\end{array}$ & [114] \\
\hline Fish & Parastromateus niger & Viscera & Peptides & Antioxidant & [115] \\
\hline Fish & Magalaspis cordyla & Viscera & Peptides & Antioxidant & [116] \\
\hline Fish & Magalaspis cordyla & Skin & Peptides & Antioxidant & [117] \\
\hline Fish & Otolithes ruber & Skin & Peptides & Antioxidant & [118] \\
\hline Bivalve & Sepia officinalis & Skin and viscera & Protein hydrolysates & Antioxidant & [119] \\
\hline Fish & Oncorhynchus keta & Skin & Peptides & Anti-hypertensive & [121] \\
\hline Jellyfish & $\begin{array}{l}\text { Aurelia sp., Cotylorhiza } \\
\text { tuberculate, Rhizostoma pulmo }\end{array}$ & Body & Hydrolyzed peptides & Antioxidant & [122] \\
\hline Jellyfish & $\begin{array}{l}\text { Rhopilema esculentus, } \\
\text { Kishinouye }\end{array}$ & Gonads & Protein hydrolysates & Antioxidant & {$[123,124]$} \\
\hline Red alga & Porphyra spp. & Leaf & Peptides & Anti-diabetic & [125] \\
\hline Red alga & Porphyra yezoensis & Leaf & Peptides & Anti-thrombotic & [126] \\
\hline
\end{tabular}

As mentioned before, macroalgae can be also used for the development of nutraceutical products. Particularly interesting is the case of two peptides (Gly-Gly-Ser-Lys and Glu-Leu-Ser) identified from proteolytic enzymes hydrolysates isolated from the red seaweed laver (Porphyra species), that significantly inhibited $\alpha$-amylase activity at $1 \mathrm{mg} / \mathrm{mL}$ 
by colorimetric method. Since this enzymatic activity can reduce blood glucose levels, the potential application of seaweed hydrolysates in diabetes treatments has been proposed [125]. Similarly, a novel peptide isolated from Nori hydrolysate inhibited the clotting factors involved in the intrinsic pathway of coagulation and, for this reason, it could be used as a functional food in the prevention of thrombosis [126].

\section{Lipids}

Lipids belong to a fundamental group of nutrients for humankind since they contribute the structure of the biological membranes [127], and act both as energy storage and key signalling molecules [128]. Their components are fatty acids (FAs), which could be classified into saturated (SFAs - without double bonds), monosaturated (MUFAs - with one double bond), and PUFAs (with two or up to six double bonds) [129]. Nowadays, essential FAs are considered to be functional foods and nutraceuticals with many benefits for human health, including the potential of reducing the risk of cardiovascular diseases, cancer, osteoporosis, diabetes [129], inflammation and neurocognitive function [130], and autoimmune diseases [131].

Among lipids, lecithin is a sticky fatty substance mainly composed of phospholipid mixtures with a small percentage of glycerides, neutral lipids, and other suspended matter. Lecithin was used for its emulsifying properties in nutraceutical (i.e., lecithin nanovesicles as supplementary food) [132], pharmaceutical (i.e., hypercholesterolemia, neurologic disorders and liver ailments) [133], and cosmetic sectors (i.e., beauty lotions and cosmetic oil) (Table 4) [134]. Marine lecithin was mostly isolated and characterized from squid (Todarodes pacificus) viscera residues de-oiled by supercritical carbon dioxide $\left(\mathrm{SC}-\mathrm{CO}_{2}\right)$ extraction. In particular, the main phospholipids of lecithin from squid viscera were phosphatidylcholine and phosphatidylethanolamine $[135,136]$. Some differences in the composition of the phospholipids of squid viscera arose [137] and can be probably explained by variations in habitat, food intake, fishing seasons of sampled organisms, and isolation/quantification processes. However, in other studies, the composition of these phospholipids from squid viscera was almost the opposite [137].

Table 4. Lipids from seafood wastes, together with taxa, species and tissue from which they were isolated, and their biotechnological application.

\begin{tabular}{|c|c|c|c|c|c|}
\hline Taxa & Species & Tissue & Product & Biological Activity & Reference \\
\hline Cephalopod & Todarodes pacificus & Viscera residues & Lecithin & Emulsifying properties & {$[135,136]$} \\
\hline Crustacean & Jasus edwardsii & Liver & PUFA & $\begin{array}{l}\text { Anti-inflammatory, } \\
\text { anti-hypertensive, } \\
\text { anti-diabetic }\end{array}$ & [138] \\
\hline Crustacean & Pandalus borealis & Head, shell and tail & EPA and DHA & $\begin{array}{l}\text { Anti-inflammatory, } \\
\text { anti-hypertensive, } \\
\text { anti-diabetic }\end{array}$ & [139] \\
\hline Fish & Rastrelliger kanagurta & Ground skin & EPA and DHA & $\begin{array}{l}\text { Anti-inflammatory, } \\
\text { anti-hypertensive, } \\
\text { anti-diabetic }\end{array}$ & [140] \\
\hline Fish & Thunnus tonggol & Head & $\begin{array}{l}\text { DHA, omega-3 } \\
\text { and -6 FAs }\end{array}$ & $\begin{array}{l}\text { Anti-inflammatory, } \\
\text { anti-hypertensive, } \\
\text { anti-diabetic }\end{array}$ & [141] \\
\hline Fish & Salmo salar & $\begin{array}{l}\text { Belly part, trimmed muscle, } \\
\text { frame bone and skin }\end{array}$ & Oil & $\begin{array}{l}\text { Free radical } \\
\text { scavenging }\end{array}$ & [142] \\
\hline Bivalve & Perna canaliculus & Body & PUFA/Lyprinol $^{\circledR}$ & $\begin{array}{l}\text { Anti-inflammatory } \\
\text { and anti-arthritis }\end{array}$ & {$[143,144]$} \\
\hline
\end{tabular}

Lipids extracted from the liver of the Australian lobster (Jasus edwardsii), using SC$\mathrm{CO}_{2}$, contained high concentrations of PUFA and low levels of contaminants such as lead, arsenic, mercury and cadmium [138]. So, lipids extracted from the liver of lobsters may be useful in the prevention and treatment of several disorders and diseases including 
coronary heart disease, rheumatoid arthritis, asthma, cancers, diabetes. A deep red oil rich in omega-3 PUFAs, especially EPA and DHA, can be also obtained from the by-products (head, shell and tail) of the Northern shrimp (Pandalus borealis) [139] and from the ground skin of the Indian mackerel (Rastrelliger kanagurta). In particular, oil extracted from Indian mackerel had the highest recoveries of PUFAs [140]. When ethanol was added as a cosolvent of SC- $\mathrm{CO}_{2}$, higher recovery of PUFAs, especially DHA, omega-3, and omega-6, from fish by-products (e.g., head of the longtail tuna Thunnus tonggol) was obtained [141]. Interestingly, oils extracted from various salmon by-products (belly part, trimmed muscle, frame bone and skin) with different techniques (hexane extraction, $\mathrm{SC}-\mathrm{CO}_{2}$ and pressed oil) did not show any differences in fatty acid composition. However, significant variation was detected in free radical scavenging activity, since oils extracted by $\mathrm{SC}-\mathrm{CO}_{2}$ exhibited greater antioxidant properties than those extracted by hexane [142].

A good example of commercialised product is Lyprinol ${ }^{\circledR}$, a lipid fraction of the freeze-dried extract from the farmed green-lipped mussel Perna canaliculus. Due to its antiinflammatory activities, the drug is currently sold to reduce the inflammatory processes related to arthritis [143,144].

Considering lipids from waste sources, it is important to underline the importance of squalene as a bioactive molecule. Squalene is a natural lipid belonging to the terpenoid family, which partly originates from endogenous cholesterol synthesis and partly from dietary sources, especially in populations consuming large amounts of olive oil or shark liver, olives, wheat germ, and rice bran [145]. Squalene is considered an excellent emollient and moisturizer for the skin, also having antioxidant and anti-cancer properties, to relieve skin irritations and/or tumors [146,147].

A few words should also be addressed to vitamin E, which is a lipid-soluble antioxidant occurring both in plants and animals for the protection of biological membranes against lipid peroxidation. Four homologue pairs $(\alpha-, \beta-, \gamma-, \delta$-tocopherols and -tocotrienols) have been described, with the $\alpha$ form being the most active [148]. Marine tocopherols have been firstly isolated from salmon eggs and subsequently from tissues and organs of several fishes, making them a considerable source of these beneficial molecules [149].

\section{Carotenoids}

Salmons, crustaceans, and shrimps processing wastes could be an important source of carotenoids (e.g., astaxanthin; Table 5) [150-152]. On one side, the intake of carotenoids from food or supplementation should be carefully considered due to the lack of specific biosynthetic pathways in humans [153]. On the other side, carotenoids are interesting bioactive molecules able to mitigate the damaging effect of oxidative stress [154]. In particular, a positive link between higher dietary intake, tissue concentrations of carotenoids, and lower risk of chronic diseases was found [155]. Moreover, the antioxidant activity of astaxanthin modulates the biological functions related to lipid peroxidation, having beneficial effects on chronic diseases, such as cardiovascular diseases, macular degeneration, and cancer [150]. In the specific case of astaxanthin, [156] its oral administration of $1 \mathrm{mg} / \mathrm{kg} /$ day for 14 days significantly reduced hepatic metastasis in rats, suggesting an important role in enhancing the immunological response through the inhibition of stress-induced lipid peroxidation. Astaxanthin and its esters displayed a strong antioxidant activity with increasing extract concentration [157]. Furthermore, astaxanthin had an anti-proliferative effect on human laryngeal carcinoma cells (Hep 2 cells), as demonstrated by Sila et al. [157]. Interestingly, to improve the stability of astaxanthin obtained from shrimp shells (Litopenaeus vannamei), encapsulation in alginate-chitosan beads was attempted for allowing its real use as a functional ingredient [158].

The content of fucoxanthin, a carotenoid extracted from the macroalga Undaria pinnatifida, is also used to control eutrophication and aids the sustainable development of aquaculture [159]. It was lower than the fucoxanthin content found in Japanese commercial wakame products, probably because of the different places and months of collection. 
Fucoxanthin extracted from fresh samples exerted a potent antioxidant activity that was higher than the commercial algae due to the loss of phenols and fucoxanthin during processing [160]. Similarly, fucoxanthin extracted from the species Sargassum wightii Greville showed antioxidant activity in vitro and inhibition of ACE, with potential application as a food ingredient to overcome hypertension [161].

Table 5. Carotenoids from seafood wastes, together with taxa, species and tissue from which they were isolated, and their biotechnological application.

\begin{tabular}{cccccc}
\hline Taxa & Species & Tissue & Product & Biological Activity & Reference \\
\hline Crustacean & Litopenaeus vannamei & Shell & Astaxanthin & Antioxidant & [158] \\
Brown alga & Undaria pinnatifida & Leaf & Fucoxanthin & Antioxidant & [159] \\
Brown alga & Sargassum wightii & Leaf & Fucoxanthin & Antioxidant and ACE inhibition & [161] \\
\hline
\end{tabular}

\section{Polysaccharides}

Crustaceans, shrimps, and crabs are the main sources of chitin from the sea [162]. The most important derivative of chitin is chitosan, obtained through partial deacetylation of chitin under alkaline conditions or enzymatic hydrolysis in the presence of a chitin deacetylase [162]. Several studies proved that chitosan and its derivatives have antioxidant, anti-microbial and anti-viral activities [163-166]. Chitin, chitosan, and their derivatives also act as inhibitors of ACE, an enzyme associated with hypertension. Chemical methods for obtaining chitin from marine wastes (shrimp shells and crabs) provided demineralization and deproteinization, with the use of strong acids or base. Meanwhile, biological methods utilize enzymatic treatment by protease and microbial fermentation [167].

Interesting studies demonstrated the availability of chitin and chitosan in various marine organisms, as in the case of the eggs of the snail Rapana venosa and the exoskeleton of the marine crab Eriphia verrucosa [168] or the scales of the Red snapper fish (Lutjanus sp.) [169], containing chitosan available for biotechnological, agricultural and industrial purposes (Table 6). Moreover, chiton shells were also found to contain a higher abundance of chitin and chitosan than commercial products [170], and Sepia prashadi cuttlebone, which proved to store a great content of these compounds, as compared to other sources (e.g., crab shells) [171]. Sulfated polysaccharides extracted from the macroalgae Gracilaria caudata and Gracilaria debilis by enzymatic and water extraction, respectively, showed antioxidant activity in a concentration-dependent manner [172,173]. The antioxidant capability of these polysaccharides was evaluated in vitro by ferrous ion chelating ability and total antioxidant capacity and in vivo using an oxidative stress rat model induced by 2,2 '-azobis (2-methylpropionamidine) dihydrochloride (ABAP) [173].

Carbohydrate complexes, named glycosaminoglycans (GAGs, e.g., chondroitin sulphate, dermatan sulphate, hyaluronic acid), are another class of polysaccharides with interesting bioactivities including, anti-viral, anti-metastatic, anti-inflammatory and anticoagulant ones, plus a great potentiality in tissue engineering. The therapeutic properties normally depend on the amount and pattern of sulfate groups along the disaccharide chain. GAGs have been extracted from numerous marine organisms that may represent a seafood waste of fishery, aquaculture and industrial processes such as, sea urchins, sea cucumbers, sea squirts and shrimps [174-177]. GAGs extracted from the mussel P. canaliculus, were found to exert an important role as anti-arthritic agents. Studies were conducted on the commercial product Biolane ${ }^{\mathrm{TM}}$, which contains GAGs plus matrix metalloprotease (MMP's), a family of enzymes necessary for normal tissue re-modelling. The main results revealed that this marine-derived mixture exhibited a wide range of beneficial activities, such as inhibition of pro-inflammatory prostaglandins (PGEs), cyclooxygenase-2 (COX-2), together with anti-platelet aggregation, and fibrinolytic potencies [178]. The cold extract from the same mussel species, extremely rich in glycosaminoglycans, was clinically proven to reduce joint pain and enhance joint mobility. It was commercialized as GlycOmega-PLUS ${ }^{\mathrm{TM}}$ [179]. 
Alginate is a polysaccharide found in the intercellular matrix of brown algae extremely rich in sodium, calcium, magnesium, strontium, and barium ions. Alginate is widely used in industry for its ability to retain water and for its gelling, viscosifier and stabilizing properties [180]. However, in addition to its use in the textile industry as a printing paste, alginate could find several applications in nutraceutical field. Alginate extracted through different techniques (water, acid, alkalase, and cellulase) from the alga Sargassum angustifolium showed antioxidant activity in a dose-dependent manner [181]. The brown seaweed cell wall and some marine invertebrates contain also a group of fucose-rich sulfated heteropolysaccharide compound, named fucoidan, which was consumed as dietary fiber in many Asian countries [182]. The structure of the fucoidan varies among species, but usually it contains L-fucose and sulfate, along with small quantities of D-galactose, Dmannose, D-xylose, and uronic acid. These fucoidans revealed various significant biological activities, such as antioxidant, anti-inflammatory, anti-allergic, anti-tumour, anti-obesity, anti-coagulant, anti-viral, anti-hepatopathy, anti-uropathy, and anti-renalpathy effects [183]. For instance, fucoidan extracted from the brown alga Sargassum polycystum showed antioxidant activity at $1000 \mu \mathrm{g} / \mathrm{mL}$ and anti-proliferative activity with $\mathrm{IC}_{50}$ of $50 \mu \mathrm{g} / \mathrm{mL}$ against the human breast cancer cell line [184]. In addition, fucoidan isolated from Sargassum wightii was found to regulate postprandial hyperglycemia in diabetic patients acting as $\alpha$-D-glucosidase inhibitor in a dose-dependent manner [185].

Table 6. Polysaccharides from seafood waste together taxa, species and tissue from which they were isolated, and their biotechnological application.

\begin{tabular}{|c|c|c|c|c|c|}
\hline Taxa & Species & Tissue & Product & Biological Activity & Reference \\
\hline Mollusc & Rapana venosa & Eggs & Chitin and chitosan & $\begin{array}{c}\text { Antioxidant, } \\
\text { anti-microbial, anti-viral } \\
\text { and anti-hypertension }\end{array}$ & [168] \\
\hline Crustacean & Eriphia verrucosa & Exoskeleton & Chitin and chitosan & $\begin{array}{l}\text { Antioxidant, } \\
\text { anti-microbial, anti-viral } \\
\text { and anti-hypertension }\end{array}$ & [168] \\
\hline Fish & Lutjanus sp. & Scales & Chitin and chitosan & $\begin{array}{l}\text { Antioxidant, } \\
\text { anti-microbial, anti-viral } \\
\text { and anti-hypertension }\end{array}$ & [169] \\
\hline Mollusc & $\begin{array}{l}\text { Several species of } \\
\text { chiton }\end{array}$ & Shell & Chitin and chitosan & $\begin{array}{l}\text { Antioxidant, } \\
\text { anti-microbial, anti-viral } \\
\text { and anti-hypertension }\end{array}$ & [170] \\
\hline Cephalopod & Sepia prashadi & Cuttlebone & Chitin and chitosan & $\begin{array}{l}\text { Antioxidant, } \\
\text { anti-microbial, anti-viral } \\
\text { and anti-hypertension }\end{array}$ & [171] \\
\hline Red alga & $\begin{array}{l}\text { Gracilaria caudata, } \\
\text { Gracilaria debilis }\end{array}$ & Leaf & $\begin{array}{c}\text { Sulfated } \\
\text { polysaccharides }\end{array}$ & Antioxidant & {$[172,173]$} \\
\hline Bivalve & Perna canaliculus & Body & $\begin{array}{c}\text { Glycosaminoglycans / } \\
\text { Biolane }^{\mathrm{TM}}\end{array}$ & Anti-inflammatory & [178] \\
\hline Bivalve & Perna canaliculus & Body & $\begin{array}{l}\text { Glycosaminoglycans / } \\
\text { GlycOmega-PLUS }\end{array}$ & Anti-arthritic & {$[179]$} \\
\hline Brown alga & Sargassum angustifolium & Leaf & Alginate & $\begin{array}{l}\text { Antioxidant } \\
\text { Antioxidant, }\end{array}$ & [181] \\
\hline Brown alga & Sargassum angustifolium & Leaf & Fucoidan & $\begin{array}{l}\text { anti-inflammatory, } \\
\text { anti-allergic, anti-tumor, } \\
\text { anti-obesity, anti-viral }\end{array}$ & [183] \\
\hline Brown alga & Sargassum polycystum & Leaf & Fucoidan & Antioxidant & [184] \\
\hline Brown alga & Sargassum wightii & Leaf & Fucoidan & Anti-diabetic & [185] \\
\hline
\end{tabular}

\section{Phenols}

As part of both animal and human diet, the nutraceutical properties assigned to phenolic compounds are almost endless including protective effects against cardiovascular disease, neurodegeneration, and cancer [186]. Macroalgae phenolic compounds, particularly phlorotannins, gained particular attention due to their specific bioactivities, including antioxidant, anti-proliferative, or anti-diabetic, despite the high abundance of polysaccharides on the macroalgae matrix made the isolation and characterization quite difficult [186]. Few examples of phenolic bioactive compounds have been reported in the literature (Table 7). For instance, a 2,5-dihydroxybenzoic acid isolated from the macroal- 
gae Laminaria digitata and Undaria pinnatifida displayed a potent $\alpha$-amylase inhibitory activity [187], whereas the polyphenol-rich extract isolated from the seaweed Sargassum vachellianum showed a good free radical scavenging ability, anti-microbial activity and effectively absorbed the UVB and UVA rays [188]. In contrast, another marine polyphenol (Dieckol), isolated from the brown alga Ecklonia cava, showed sleep-enhancing effects by increasing the amount of non-rapid eye movement sleep and decreasing wakefulness during the same hours. These results implied that Dieckol can be used as a promising herbal sleep aid with minimal side effects, unlike the existing hypnotics [189]. These macroalgae represent a considerable source of waste products since they are used in intensive aquaculture and management of the eutrophication phenomenon [159,190].

Table 7. Phenols from seafood wastes, together with taxa, species and tissue from which they were isolated, and their biotechnological application.

\begin{tabular}{|c|c|c|c|c|c|}
\hline Taxa & Species & Tissue & Product & Biological Activity & Reference \\
\hline Brown alga & $\begin{array}{l}\text { Laminaria digitata, } \\
\text { Undaria pinnatifida }\end{array}$ & Leaf & 2,5-dihydroxybenzoic acid & $\begin{array}{c}\text { Anti-diabetic } \\
(\alpha \text {-amylase inhibition) }\end{array}$ & [187] \\
\hline Brown alga & Sargassum vachellianum & Leaf & Polyphenol-rich extract & $\begin{array}{c}\text { Free radical scavenging, } \\
\text { antimicrobial activity } \\
\text { and anti-UV }\end{array}$ & [188] \\
\hline Brown alga & Ecklonia cava & Leaf & Dieckol & Sleep-enhancing & [189] \\
\hline
\end{tabular}

\section{Industrial Status and Trends}

In the last ten years, 620 scientific contributions related to marine biotechnology have been published, with a particular focus on the pharmacological and food industry [191]. More than 1000 novel compounds have been, annually, described with a focus on seafood wastes, and several examples of nutraceutical products are already sold in the market [192]. Several companies, such as Aquapreneur (www.aquapreneur.com, accessed date 15 March 2021), Sederma (http: / / www.sederma.fr, accessed date 15 March 2021), NutraIngredients (www.Nutraingredients.com, accessed date 15 March 2021), SpecialChem (http:/ / www. specialchem4cosmetics.com, accessed date 5 April 2021), Fortitech (fortitechpremixes.com, accessed date 5 April 2021), Copalis (http:/ / www.copalis.fr/, accessed date 5 April 2021), and so on, are currently working on new marine ingredients made of collagen, various peptides, GAGs, oils, calcium supplements, and classes of compounds described above (see Sections 2-8).

Food supplements containing tripeptides, dipeptides, and also free amino acids from fish gelatin and collagen are already available commercially for the preservation of bones and tendon integrity [193]. Moreover, a huge production of fish oil as nutraceutical products was also performed all over the world. Oils contain elevated levels of long-chain omega-3 PUFAs, exhibiting beneficial activities [194]. For instance, Lovaza ${ }^{\circledR}$, which contains ethyl esters of EPA (20:5) and DHA (22:6), is now available in the market to treat diabetes and cardiovascular diseases (https://www.drugs.com/pro/lovaza.html, accessed date 15 March 2021). Concerning chitosan and its derivatives, at present, several companies are involved in the production of medical and food products with nutraceutical purposes. Common examples are Seatone ${ }^{\circledR}$ and Lyprinol ${ }^{\circledR}$ obtained from mussels that are now sold as functional foods in anti-arthritic and anti-inflammatory treatments [195]. Concluding, it must be considered that additional compounds are still the subject of clinical trials, as in the case of the fish hydrolysate Gabolysat [196], and the mussel and fish neurotoxin Tetrodotoxin (TTX), which is investigated for its analgesic properties [197].

\section{Conclusions and Future Perspectives}

This review is aimed at an environmentally friendly and sustainable use of marine resources, to foresee possible economic benefits for the sector. The data reported show that seafood by-products contain a range of valuable biomolecules, fully appreciating what is usually considered a "waste" and exploiting them to improve human wellness and health. 
In ancient times, hunting, fishing and gathering were three fundamental practices for food supply. Nowadays, humans still relieve on marine natural resources as one of the main ingredients for human consumption. Since oceans occupy more than 70\% of the Earth's surface, their high biodiversity makes them a target for searching raw resources, including natural and bioactive compounds. With the increase of the global human population, marine organisms play a role not only as a supply of high-quality food, but also as a source of various compounds for pharmaceuticals, cosmetics, and nutraceutical industries. In fact, several bioactive molecules were isolated from the sea, with beneficial properties including antioxidant, anti-microbial, anti-diabetic, anti-proliferative, anti-obesity, anti-Alzheimer, anti-fibrotic, neuroprotection, sleep-enhancing, lipid-lowering, wound healing, and skin protection activities. Exploiting marine resources in a sustainable way, to satisfy the food requirement of the growing human population, puts high pressure on the natural resources of the planet. Hence, more rational exploitation of the available natural assets should be adopted. It is imperative to develop functional foods from marine products, and in particular from fishery discards, since they are widely available and they can prevent or cure various diseases. Ineffective use of the marine raw materials and the common use of non-selective fishing gears generate a loss of up to $50 \%$ of the marine captures, that are discarded in the sea, and up to $80 \%$ of the seafood raw material, that is not processed and discarded. A huge amount of wastes generated during seafood industrial processing can be properly handled to obtain raw materials. This management requires a green revolution in industrial processing with the integration of standard processing methods with environmentally friendly and cost-effective ones, to achieve sustainable production with a low ecological footprint. In addition, seafood discards are considered hazardous to the environment and can create a serious waste disposal problem. Here, we reported data demonstrating the opportunity to effectively reuse wastes and by-products from aquaculture and fisheries, which would potentially go to waste, rather than being used to produce high-quality nutraceuticals for human consumption.

The identification of functional ingredients and their nutraceutical application is a growing field. Interesting compounds, such as bioactive peptides, polysaccharides, polyunsaturated fats, carotenoids, polyphenolic compounds, minerals, collagen, gelatin, saponins, phycobiliproteins, and phytosterols, are in fact abundant in fish bycatch and food industrial scraps. The major advantages of extracting waste-derived nutraceuticals, besides their low costs, are found in the easy availability of raw materials, high recovery rates, interesting functional properties of the isolated substances, and the aforementioned potential applications.

In addition, the use of waste compounds opens new perspectives in integrative aquaculture. For example, with the potential use of edible seaweeds in phyto-depuration techniques applicable for multispecies culture systems, species can be sold as food or food complements after the production cycle. Indeed, the use of wastes in nutraceuticals has led to various answers to common issues, such as recycling, increasing of profits by industries, reduction of human footprint activities, and sustainability of marine sources.

However, many aspects should be faced, as in the case of the relationships between processing procedure and the functionality of final products. Further studies are required to evaluate the best procedures to assure the stability of marine bioactive molecules during the processing and storage, as well as the uniformity of the bioactive contents according to natural variability over the fishing areas, the seasons, and the production processes themselves. These latter issues are still limiting the successful exploitation of seafood by-products for the food industry, and further research is needed to bypass them and allow the effective production of compounds for human wellbeing.

Author Contributions: Conceptualization of the review, M.C. and V.Z.; bibliographic research and original draft preparation, M.M., R.E. and N.R.; preparation of figure and tables, T.V.; review and editing of the text, M.C. and V.Z. All authors have read and agreed to the published version of the manuscript. 
Funding: This research was supported by Antitumor Drugs and Vaccines from the Sea (ADViSE)" project (PG/2018/0494374).

Acknowledgments: Mirko Mutalipassi and Nadia Ruocco were supported by the research grants on "Antitumor Drugs and Vaccines from the Sea (ADViSE)" project (PG/2018/0494374). Roberta Esposito was supported by a PhD (PhD in Biology, University of Naples Federico II) fellowship funded by the Photosynthesis 2.0 project of the Stazione Zoologica Anton Dohrn. R. Messina kindly revised the English text.

Conflicts of Interest: The authors declare no conflict of interest.

\section{References}

1. Pauly, D.; Zeller, D.; Palomares, M.L.D. Sea around Us. Concepts, Design and Data (seaaroundus.org). Available online: http:/ / www.seaaroundus.org/data/\#/spatial-catch (accessed on 15 March 2021).

2. Zeller, D.; Cashion, T.; Palomares, M.; Pauly, D. Global marine fisheries discards: A synthesis of reconstructed data. Fish Fish. 2018, 19, 30-39. [CrossRef]

3. Catchpole, T.L.; Gray, T.S. Reducing discards of fish at sea: A review of European pilot projects. J. Environ. Manag. 2010, 91, 717-723. [CrossRef]

4. Love, D.C.; Fry, J.P.; Milli, M.C.; Neff, R. Wasted seafood in the United States: Quantifying loss from production to consumption and moving toward solutions. Glob. Environ. Chang. 2015, 35, 116-124. [CrossRef]

5. Karadeniz, F.; Kim, S.-K. Trends in the Use of Seafood Processing By-Products in Europe; Springer Science and Business Media LLC.: Berlin, Germany, 2013; Volume 9781461495, pp. 11-19.

6. Boopendranath, M.R. Waste minimisation in fishing operations. Fish. Technol. 2012, 49, 109-119.

7. Suuronen, P.; Chopin, F.; Glass, C.; Løkkeborg, S.; Matsushita, Y.; Queirolo, D.; Rihan, D. Low impact and fuel efficient fishing-Looking beyond the horizon. Fish. Res. 2012, 119-120, 135-146. [CrossRef]

8. Andrady, A.L. Microplastics in the marine environment. Mar. Pollut. Bull. 2011, 62, 1596-1605. [CrossRef] [PubMed]

9. Macfadyen, G.; Huntington, T.; Cappell, R. Abandoned, Lost or Otherwise Discarded Fishing Gear; FAO: Rome, Italy, 2009.

10. Thompson, R.C.; La Belle, B.E.; Bouwman, H.; Neretin, L. Marine Debris as a Global Environmental Problem: Introducing a Solutions-Based Framework Focused on Plastic. A STAP Information Document. Available online: https://www.thegef.org/ sites/default/files/publications/STAP_MarineDebris_-_website_1.pdf (accessed on 5 April 2021).

11. Link, J.; Segal, B.; Casarini, L.M. Abandoned, lost or otherwise discarded fishing gear in Brazil: A review. Perspect. Ecol. Conserv. 2019, 17, 1-8. [CrossRef]

12. Bellido, J.M.; Santos, M.B.; Pennino, M.G.; Valeiras, X.; Pierce, G. Fishery discards and bycatch: Solutions for an ecosystem approach to fisheries management? Hydrobiology 2011, 670, 317-333. [CrossRef]

13. Binns, C.W. Discards in the world's marine fisheries: An update. FAO Fish. Tech. Pap. 2011, 16, 177-178.

14. Gilman, E.; Roda, A.P.; Huntington, T.; Kennelly, S.J.; Suuronen, P.; Chaloupka, M.; Medley, P.A.H. Benchmarking global fisheries discards. Sci. Rep. 2020, 10, 1-8. [CrossRef]

15. Pauly, D.; Zeller, D. Catch reconstructions reveal that global marine fisheries catches are higher than reported and declining. Nat. Commun. 2016, 7, 10244. [CrossRef]

16. Environmental Justice Foundation Squandering the Seas: How Shrimp Trawling is Threatening Ecological Integrity and Food Security around the World: A Report. 2003. Available online: https://www.eldis.org/document/A12837 (accessed on 15 April 2021).

17. Najmudeen, T.; Sathiadhas, R. Economic impact of juvenile fishing in a tropical multi-gear multi-species fishery. Fish. Res. 2008, 92, 322-332. [CrossRef]

18. Nunoo, F.; Boateng, J.O.; Ahulu, A.M.; Agyekum, K.A.; Sumaila, U.R. When trash fish is treasure: The case of Ghana in West Africa. Fish. Res. 2009, 96, 167-172. [CrossRef]

19. Stergiou, K.I.; Machias, A.; Somarakis, S.; Kapantagakis, A. Can we define target species in Mediterranean trawl fisheries? Fish. Res. 2003, 59, 431-435. [CrossRef]

20. Bazi, C.C.; Pessatti, M.; Junior, C.R. Utilization of the jellyfish occuring in the bycatch for human consumption in the south of Brazil. Panam. J. Aquat. Sci. 2019, 14, 13-23.

21. Nagata, R.M.; Haddad, M.A.; Nogueira, M. The nuisance of medusae (Cnidaria, Medusozoa) to shrimp trawls in central part of southern Brazilian Bight, from the perspective of artisanal fishermen. Panam. J. Aquat. Sci. 2009, 4, 312-325.

22. Lucas, C.H.; Dawson, M.N. What Are Jellyfishes and Thaliaceans and Why Do They Bloom; Springer Science and Business Media LLC.: Berlin, Germany, 2014; pp. 9-44.

23. Ohta, N.; Sato, M.; Ushida, K.; Kokubo, M.; Baba, T.; Taniguchi, K.; Urai, M.; Kihira, K.; Mochida, J. Jellyfish mucin may have potential disease-modifying effects on osteoarthritis. BMC Biotechnol. 2009, 9, 98. [CrossRef] [PubMed]

24. Moran, D.L.; Underwood, M.Y.; Gabourie, T.A.; Lerner, K.C. Effects of a Supplement Containing Apoaequorin on Verbal Learning in Older Adults in the Community. Adv. Mind Body Med. 2016, 30, 4-11.

25. Moran, D.L.; Tetteh, A.O.; Goodman, R.E.; Underwood, M.Y. Safety assessment of the calcium-binding protein, apoaequorin, expressed by Escherichia coli. Regul. Toxicol. Pharmacol. 2014, 69, 243-249. [CrossRef] [PubMed] 
26. Esteban, M.; García, A.; Ramos, P.; Márquez, M. Evaluation of fruit-vegetable and fish wastes as alternative feedstuffs in pig diets. Waste Manag. 2007, 27, 193-200. [CrossRef]

27. Bhaskar, N.; Suresh, P.; Sakhare, P.; Sachindra, N. Shrimp biowaste fermentation with Pediococcus acidolactici CFR2182: Optimization of fermentation conditions by response surface methodology and effect of optimized conditions on deproteination/demineralization and carotenoid recovery. Enzym. Microb. Technol. 2007, 40, 1427-1434. [CrossRef]

28. De Arruda, L.F.; Borghesi, R.; Oetterer, M. Use of fish waste as silage: A review. Braz. Arch. Biol. Technol. 2007, 50, 879-886. [CrossRef]

29. Vázquez, J.; Nogueira, M.; Durán, A.; Prieto, M.A.; Rodríguez-Amado, I.; Rial, D.; González, M.; Murado, M. Preparation of marine silage of swordfish, ray and shark visceral waste by lactic acid bacteria. J. Food Eng. 2011, 103, 442-448. [CrossRef]

30. Ms, R.V.B.; Ae, R.V.G. Fish Processing Wastes as a Potential Source of Proteins, Amino Acids and Oils: A Critical Review. J. Microb. Biochem. Technol. 2013, 5, 107-129. [CrossRef]

31. Venugopal, V.; Lele, S.S. Nutraceuticals and bioactive compounds from seafood processing waste. In Springer Handbook of Marine Biotechnology; Kim, S.K., Ed.; Springer: Berlin, Germany, 2015; pp. 1405-1425, ISBN 9783642539718.

32. Nazzaro, F.; Fratianni, F.; Ombra, M.N.; D'Acierno, A.; Coppola, R. Recovery of biomolecules of high benefit from food waste. Curr. Opin. Food Sci. 2018, 22, 43-54. [CrossRef]

33. Venugopal, V. Seafood Processing: Adding Value through Quick Freezing, Retortable Packaging, and Cook-Chilling; CRC Press: Boca Raton, FL, USA, 2006; ISBN 9781420027396.

34. Ferraro, V.; Cruz, I.B.; Jorge, R.F.; Malcata, F.X.; Pintado, M.M.; Castro, P. Valorisation of natural extracts from marine source focused on marine by-products: A review. Food Res. Int. 2010, 43, 2221-2233. [CrossRef]

35. Olsen, R.L.; Toppe, J.; Karunasagar, I. Challenges and realistic opportunities in the use of by-products from processing of fish and shellfish. Trends Food Sci. Technol. 2014, 36, 144-151. [CrossRef]

36. Gates, K.W. Marine Products for Healthcare: Functional and Bioactive Nutraceutical Compounds from the Ocean, Vazhiyil Venugopal. J. Aquat. Food Prod. Technol. 2010, 19, 48-54. [CrossRef]

37. Mao, X.; Guo, N.; Sun, J.; Xue, C. Comprehensive utilization of shrimp waste based on biotechnological methods: A review. J. Clean. Prod. 2017, 143, 814-823. [CrossRef]

38. Sasidharan, A.; Venugopal, V. Proteins and Co-products from Seafood Processing Discards: Their Recovery, Functional Properties and Applications. Waste Biomass Valorization 2020, 11, 5647-5663. [CrossRef]

39. Nguyen, T.T.; Barber, A.R.; Corbin, K.; Zhang, W. Lobster processing by-products as valuable bioresource of marine functional ingredients, nutraceuticals, and pharmaceuticals. Bioresour. Bioprocess. 2017, 4, 1-19. [CrossRef]

40. Fasciglione, G.; Goñi, M.; Yommi, A.; Perez-Bravo, J.; Ortueta, R.; Scampini, A.; Buffa, L.; Andreu, A.; Creus, C. Revaluation of waste from fishing industry through generation of chitosan coatings to improve quality and extend shelf-life of minimally processed lettuce. Postharvest Biol. Technol. 2020, 170, 111310. [CrossRef]

41. Bonecco, M.B.; Martínez Sáenz, M.G.; Buffa, L.M. Chitosan, from residue to industry. In Advances in Physicochemical Properties of Biopolymers; Masuell, M., Renard, D., Eds.; Bentham Science Publishers: Sharjah, United Arab Emirates, 2017; pp. 224-256, ISBN 978-1-68108-545-6.

42. Kim, S.-K.; Senevirathne, M. Membrane Bioreactor Technology for the Development of Functional Materials from Sea-Food Processing Wastes and Their Potential Health Benefits. Membranes 2011, 1, 327-344. [CrossRef]

43. Freitas, A.C.; Rodrigues, D.; Rocha-Santos, T.A.; Gomes, A.M.; Duarte, A.C. Marine biotechnology advances towards applications in new functional foods. Biotechnol. Adv. 2012, 30, 1506-1515. [CrossRef]

44. Zhang, Y.; He, S.; Simpson, B.K. Enzymes in food bioprocessing-Novel food enzymes, applications, and related techniques. Curr. Opin. Food Sci. 2018, 19, 30-35. [CrossRef]

45. Menon, V.V. Enzymes from Seafood Processing Waste and Their Applications in Seafood Processing. Adv. Food Nutr. Res. 2016, 78, 47-69. [CrossRef]

46. Gustavsson, J.; Cederberg, C.; Sonesson, U.; van Otterdijk, R.; Meybeck, A. Global Food Losses and Food Waste: Extent, Causes and Prevention. Available online: http://www.fao.org/fileadmin/user_upload/ags/publications/GFL_web.pdf (accessed on 2 February 2021).

47. Al Khawli, F.; Martí-Quijal, F.J.; Ferrer, E.; Ruiz, M.-J.; Berrada, H.; Gavahian, M.; Barba, F.J; de la Fuente, B. Aquaculture and its by-products as a source of nutrients and bioactive compounds. Adv. Food Nutr. Res. 2020, 92, 1-33. [CrossRef]

48. Hamed, I.; Ozogul, F.; Ozogul, Y.; Regenstein, J.M. Marine Bioactive Compounds and Their Health Benefits: A Review. Compr. Rev. Food Sci. Food Saf. 2015, 14, 446-465. [CrossRef]

49. Kandra, P.; Challa, M.M.; Jyothi, H.K.P. Efficient use of shrimp waste: Present and future trends. Appl. Microbiol. Biotechnol. 2012, 93, 17-29. [CrossRef]

50. Wade, N.M.; Gabaudan, J.; Glencross, B.D. A review of carotenoid utilisation and function in crustacean aquaculture. Rev. Aquac. 2015, 9, 141-156. [CrossRef]

51. Higuera-Ciapara, I.; Félix-Valenzuela, L.; Goycoolea, F.M. Astaxanthin: A Review of its Chemistry and Applications. Crit. Rev. Food Sci. Nutr. 2006, 46, 185-196. [CrossRef] [PubMed]

52. Lim, K.C.; Yusoff, F.M.; Shariff, M.; Kamarudin, M.S. Astaxanthin as feed supplement in aquatic animals. Rev. Aquac. 2018, 10, 738-773. [CrossRef] 
53. Kumar, C.S.; Ganesan, P.; Suresh, P.V.; Bhaskar, N. Seaweeds as a source of nutritionally beneficial compounds-A review. J. Food Sci. Technol. 2008, 45, 1-13.

54. Carvalho, L.G.; Pereira, L. Review of marine algae as source of bioactive metabolites. In Marine Algae: Biodiversity, Taxonomy, Environmental Assessment, and Biotechnology; Pereira, L., Neto, J.M., Eds.; CRC Press: Boca Raton, FL, USA, 2014; pp. 195-227, ISBN 9781466581814.

55. Ścieszka, S.; Klewicka, E. Algae in food: A general review. Crit. Rev. Food Sci. Nutr. 2019, 59, 3538-3547. [CrossRef] [PubMed]

56. FAO. The State of World Fisheries and Aquaculture; FAO: Rome, Italy, 2020.

57. Ferdouse, F.; Holdt, S.L.; Smith, R.; Murúa, P.; Yang, Z. The global status of seaweed production, trade and utilization. FAO Globefish Res. Program. 2018, 124, 120.

58. Silva, T.H.; Moreira-Silva, J.; Marques, A.L.P.; Domingues, A.; Bayon, Y.; Reis, R.L. Marine Origin Collagens and Its Potential Applications. Mar. Drugs 2014, 12, 5881-5901. [CrossRef]

59. Coppola, D.; Oliviero, M.; Vitale, G.A.; Lauritano, C.; D'Ambra, I.; Iannace, S.; De Pascale, D. Marine Collagen from Alternative and Sustainable Sources: Extraction, Processing and Applications. Mar. Drugs 2020, 18, 214. [CrossRef]

60. Omura, Y.; Urano, N.; Kimura, S. Occurrence of fibrillar collagen with structure of $(\alpha 1) 2 \alpha 2$ in the test of sea urchin Asthenosoma ijimai. Comp. Biochem. Physiol. Part B Biochem. Mol. Biol. 1996, 115, 63-68. [CrossRef]

61. Nagai, T.; Suzuki, N. Partial characterization of collagen from purple sea urchin (Anthocidaris crassispina) test. Int. J. Food Sci. Technol. 2000, 35, 497-501. [CrossRef]

62. Kimura, S.; Takema, Y.; Kubota, M. Octopus skin collagen. Isolation and characterization of collagen comprising two distinct alpha chains. J. Biol. Chem. 1981, 256, 13230-13234. [CrossRef]

63. Kimura, S.; Miura, S.; Park, Y.-H. Collagen as the Major Edible Component of Jellyfish (Stomolophus nomural). J. Food Sci. 1983, 48, 1758-1760. [CrossRef]

64. Kimura, S.; Zhu, X.-P.; Matsui, R.; Shijoh, M.; Takamizawa, S. Characterization of Fish Muscle Type I Collagen. J. Food Sci. 1988, 53, 1315-1318. [CrossRef]

65. Nagai, T.; Araki, Y.; Suzuki, N. Collagen of the skin of ocellate puffer fish (Takifugu rubripes). Food Chem. 2002, 78, $173-177$. [CrossRef]

66. Meyers, M.A.; Lin, Y.S.; Olevsky, E.A.; Chen, P.-Y. Battle in the Amazon: Arapaima versus Piranha. Adv. Eng. Mater. 2012, 14, B279-B288. [CrossRef]

67. Regenstein, J.M.; Zhou, P. Collagen and gelatin from marine by-products. In Maximising the Value of Marine By-Products; Shahidi, F., Ed.; Woodhead Publishing: Shaxton, UK, 2007; pp. 279-303, ISBN 9781845690137.

68. Salvatore, L.; Gallo, N.; Natali, M.L.; Campa, L.; Lunetti, P.; Madaghiele, M.; Blasi, F.S.; Corallo, A.; Capobianco, L.; Sannino, A. Marine collagen and its derivatives: Versatile and sustainable bio-resources for healthcare. Mater. Sci. Eng. C 2020, $113,110963$. [CrossRef] [PubMed]

69. Lim, Y.-S.; Ok, Y.-J.; Hwang, S.-Y.; Kwak, J.-Y.; Yoon, S. Marine Collagen as A Promising Biomaterial for Biomedical Applications. Mar. Drugs 2019, 17, 467. [CrossRef]

70. Hashim, P.; Mohd Ridzwan, M.S.; Bakar, J.; Mat Hashim, D. Collagen in food and beverage industries. Int. Food Res. J. 2015, 22, $1-8$.

71. King'ori, A.M. A Review of the Uses of Poultry Eggshells and Shell Membranes. Int. J. Poult. Sci. 2011, 10, 908-912. [CrossRef]

72. Benjakul, S.; Kittiphattanabawon, P.; Regenstein, J.M. Fish Gelatin. In Food Biochemistry and Food Processing; Wiley: Hoboken, NJ, USA, 2012; pp. 388-405.

73. Karim, A.; Bhat, R. Fish gelatin: Properties, challenges, and prospects as an alternative to mammalian gelatins. Food Hydrocoll. 2009, 23, 563-576. [CrossRef]

74. Boran, G.; Regenstein, J.M. Fish Gelatin. In Advances in Food and Nutrition Research; Elsevier BV: Amsterdam, The Netherlands, 2010; Volume 60, pp. 119-143.

75. Irwandi, J.; Faridayanti, S.; Mohamed, E.S.M.; Hamzah, M.S.; Torla, H.H.; Man, Y.B.C. Extraction and characterization of gelatin from different marine fish species in Malaysia. Int. Food Res. J. 2009, 16, 381-389.

76. Gómez-Guillén, M.; Me, L.-C.; Giménez, B.; Montero, P. Antioxidant and antimicrobial peptide fractions from squid and tuna skin gelatin. In Sea By-Products as a Real Material: New Ways of Application; Le Bihan, E., Ed.; Kerala: Madrid, Spain, 2010; Volume 661, pp. 89-115, ISBN 9788178954851.

77. Aleman, A.; Giménez, B.; Montero, P.; Gómez-Guillén, M.C. Antioxidant activity of several marine skin gelatins. LWT 2011, 44, 407-413. [CrossRef]

78. Ngo, D.-H.; Ryu, B.; Vo, T.-S.; Himaya, S.; Wijesekara, I.; Kim, S.-K. Free radical scavenging and angiotensin-I converting enzyme inhibitory peptides from Pacific cod (Gadus macrocephalus) skin gelatin. Int. J. Biol. Macromol. 2011, 49, 1110-1116. [CrossRef]

79. Chen, T.; Hou, H.; Lu, J.; Zhang, K.; Li, B. Protective effect of gelatin and gelatin hydrolysate from salmon skin on UV irradiationinduced photoaging of mice skin. J. Ocean. Univ. China 2016, 15, 711-718. [CrossRef]

80. Liang, J.; Pei, X.; Zhang, Z.; Wang, N.; Wang, J.; Li, Y. The Protective Effects of Long-Term Oral Administration of Marine Collagen Hydrolysate from Chum Salmon on Collagen Matrix Homeostasis in the Chronological Aged Skin of Sprague-Dawley Male Rats. J. Food Sci. 2010, 75, H230-H238. [CrossRef]

81. Fan, J.; Zhuang, Y.; Li, B. Effects of Collagen and Collagen Hydrolysate from Jellyfish Umbrella on Histological and Immunity Changes of Mice Photoaging. Nutrient 2013, 5, 223-233. [CrossRef] [PubMed] 
82. Kim, S.K.; Venkatesan, J. Bycatch utilization in Asia. In Seafood Processing By-Products: Trends and Applications; Kim, S., Ed.; Springer-Verlag: New York, NY, USA, 2014; pp. 1-597, ISBN 9781461495901.

83. Morishige, H.; Sugahara, T.; Nishimoto, S.; Muranaka, A.; Ohno, F.; Shiraishi, R.; Doi, M. Immunostimulatory effects of collagen from jellyfish in vivo. Cytotechnology 2011, 63, 481-492. [CrossRef] [PubMed]

84. Gharibzahedi, S.M.T.; Jafari, S.M. The importance of minerals in human nutrition: Bioavailability, food fortification, processing effects and nanoencapsulation. Trends Food Sci. Technol. 2017, 62, 119-132. [CrossRef]

85. Trailokya, A.; Srivastava, A.; Bhole, M.; Zalte, N. Calcium and calcium salts. J. Assoc. Physicians India 2017, 65, 100-103.

86. Das, J.K.; Salam, R.A.; Kumar, R.; Bhutta, Z.A. Micronutrient fortification of food and its impact on woman and child health: A systematic review. Syst. Rev. 2013, 2, 67. [CrossRef] [PubMed]

87. Jung, W.-K.; Park, P.-J.; Byun, H.-G.; Moon, S.-H.; Kim, S.-K. Preparation of hoki (Johnius belengerii) bone oligophosphopeptide with a high affinity to calcium by carnivorous intestine crude proteinase. Food Chem. 2005, 91, 333-340. [CrossRef]

88. Lee, Y.-K.; Kim, A.Y.; Min, S.-G.; Kwak, H.-S. Characteristics of milk tablets supplemented with nanopowdered eggshell or oyster shell. Int. J. Dairy Technol. 2016, 69, 337-345. [CrossRef]

89. Alsuhaibani, A.M.A. Rheological and Nutritional Properties and Sensory Evaluation of Bread Fortified with Natural Sources of Calcium. J. Food Qual. 2018, 2018, 1-7. [CrossRef]

90. Kim, S.-K.; Ravichandran, Y.D.; Kong, C.-S. Applications of Calcium and its Supplement derived from Marine Organisms. Crit. Rev. Food Sci. Nutr. 2012, 52, 469-474. [CrossRef]

91. Gkouvatsos, K.; Papanikolaou, G.; Pantopoulos, K. Regulation of iron transport and the role of transferrin. Biochim. Biophys. Acta Gen. Subj. 2012, 1820, 188-202. [CrossRef] [PubMed]

92. Lee, S.-H.; Bin Song, K. Purification of an iron-binding nona-peptide from hydrolysates of porcine blood plasma protein. Process. Biochem. 2009, 44, 378-381. [CrossRef]

93. Yun, S.; Zhang, T.; Li, M.; Chen, B.; Zhao, G. Proanthocyanidins Inhibit Iron Absorption from Soybean (Glycine max) Seed Ferritin in Rats with Iron Deficiency Anemia. Plant. Foods Hum. Nutr. 2011, 66, 212-217. [CrossRef]

94. Guo, L.; Hou, H.; Li, B.; Zhang, Z.; Wang, S.; Zhao, X. Preparation, isolation and identification of iron-chelating peptides derived from Alaska pollock skin. Process. Biochem. 2013, 48, 988-993. [CrossRef]

95. Tanna, B.; Mishra, A. Metabolites Unravel Nutraceutical Potential of Edible Seaweeds: An Emerging Source of Functional Food. Compr. Rev. Food Sci. Food Saf. 2018, 17, 1613-1624. [CrossRef]

96. Rajapakse, N.; Kim, S.-K. Nutritional and Digestive Health Benefits of Seaweed. Adv. Food Nutr. Res. 2011, 64, 17-28. [CrossRef]

97. Ren, D.; Noda, H.; Amano, H.; Nishino, T.; Nishizawa, K. Study on Antihypertensive and Antihyperlipidemic Effects of Marine Algae. Fish. Sci. 1994, 60, 83-88. [CrossRef]

98. Martins, A.; Vieira, H.; Gaspar, H.; Santos, S. Marketed Marine Natural Products in the Pharmaceutical and Cosmeceutical Industries: Tips for Success. Mar. Drugs 2014, 12, 1066-1101. [CrossRef]

99. Dicpinigaitis, P.V. Angiotensin-Converting Enzyme Inhibitor-Induced Cough. Chest 2006, 129, 169S-173S. [CrossRef]

100. Cotton, J.; Hayashi, M.A.F.; Cuniasse, P.; Vazeux, G.; Ianzer, D.; De Camargo, A.C.M.; Dive, V. Selective Inhibition of the C-Domain of Angiotensin I Converting Enzyme by Bradykinin Potentiating Peptides. Biochemistry 2002, 41, 6065-6071. [CrossRef] [PubMed]

101. Kim, S.-K.; Mendis, E. Bioactive compounds from marine processing byproducts-A review. Food Res. Int. 2006, 39, 383-393. [CrossRef]

102. Khora, S.S. Marine fish-derived bioactive peptides and proteins for human therapeutics. Int. J. Pharm. Pharm. Sci. 2013, 5, 31-37.

103. Chalamaiah, M.; Kumar, B.D.; Hemalatha, R.; Jyothirmayi, T. Fish protein hydrolysates: Proximate composition, amino acid composition, antioxidant activities and applications: A review. Food Chem. 2012, 135, 3020-3038. [CrossRef]

104. Khalili Tilami, S.; Sampels, S. Nutritional Value of Fish: Lipids, Proteins, Vitamins, and Minerals. Rev. Fish. Sci. Aquac. 2018, 26, 243-253. [CrossRef]

105. Kim, S.-K.; Wijesekara, I. Development and biological activities of marine-derived bioactive peptides: A review. J. Funct. Foods 2010, 2, 1-9. [CrossRef]

106. Ngo, D.-H.; Vo, T.-S.; Kim, S.-K. Biological Activities of Marine Bioactive Peptides. In Marine Proteins and Peptides; Wiley: Hoboken, NJ, USA, 2013; pp. 509-521.

107. Zamora-Sillero, J.; Gharsallaoui, A.; Prentice, C. Peptides from Fish By-product Protein Hydrolysates and Its Functional Properties: An Overview. Mar. Biotechnol. 2018, 20, 118-130. [CrossRef] [PubMed]

108. Mendis, E.; Rajapakse, A.N.; Kim, S.-K. Antioxidant Properties of a Radical-Scavenging Peptide Purified from Enzymatically Prepared Fish Skin Gelatin Hydrolysate. J. Agric. Food Chem. 2005, 53, 581-587. [CrossRef] [PubMed]

109. Yang, J.-I.; Ho, H.-Y.; Chu, Y.-J.; Chow, C.-J. Characteristic and antioxidant activity of retorted gelatin hydrolysates from cobia (Rachycentron canadum) skin. Food Chem. 2008, 110, 128-136. [CrossRef]

110. Šližytė, R.; Mozuraitytė, R.; Martínez-Alvarez, O.; Falch, E.; Fouchereau-Peron, M.; Rustad, T. Functional, bioactive and antioxidative properties of hydrolysates obtained from cod (Gadus morhua) backbones. Process. Biochem. 2009, 44, 668-677. [CrossRef]

111. Barkia, A.; Bougatef, A.; Ben Khaled, H.; Nasri, M. Antioxidant activities of sardinelle heads and/or viscera protein hydrolysates prepared by enzymatic treatment. J. Food Biochem. 2010, 34, 303-320. [CrossRef] 
112. Bougatef, A.; Nedjar-Arroume, N.; Manni, L.; Ravallec, R.; Barkia, A.; Guillochon, D.; Nasri, M. Purification and identification of novel antioxidant peptides from enzymatic hydrolysates of sardinelle (Sardinellaaurita) by-products proteins. Food Chem. 2010, 118, 559-565. [CrossRef]

113. Jia, J.; Zhou, Y.; Lu, J.; Chen, A.; Li, Y.; Zheng, G. Enzymatic hydrolysis of Alaska pollack (Theragra chalcogramma) skin and antioxidant activity of the resulting hydrolysate. J. Sci. Food Agric. 2010, 90, 635-640. [CrossRef] [PubMed]

114. Naqash, S.Y.; Nazeer, R.A. Antioxidant Activity of Hydrolysates and Peptide Fractions of Nemipterus japonicus and Exocoetus volitans Muscle. J. Aquat. Food Prod. Technol. 2010, 19, 180-192. [CrossRef]

115. Ganesh, R.J.; Nazeer, R.A.; Kumar, N.S.S. Purification and identification of antioxidant peptide from black pomfret, Parastromateus niger (Bloch, 1975) viscera protein hydrolysate. Food Sci. Biotechnol. 2011, 20, 1087-1094. [CrossRef]

116. Kumar, N.S.; Nazeer, R.; Jaiganesh, R. Purification and biochemical characterization of antioxidant peptide from horse mackerel (Magalaspis cordyla) viscera protein. Peptides 2011, 32, 1496-1501. [CrossRef]

117. Kumar, N.S.S.; Nazeer, R.A.; Jaiganesh, R. Purification and identification of antioxidant peptides from the skin protein hydrolysate of two marine fishes, horse mackerel (Magalaspis cordyla) and croaker (Otolithes ruber). Amino Acids 2011, 42, 1641-1649. [CrossRef]

118. Nazeer, R.; Kumar, N.S.; Ganesh, R.J. In vitro and in vivo studies on the antioxidant activity of fish peptide isolated from the croaker (Otolithes ruber) muscle protein hydrolysate. Peptides 2012, 35, 261-268. [CrossRef] [PubMed]

119. Ktari, N.; Fakhfakh, N.; Balti, R.; Ben Khaled, H.; Nasri, M.; Bougatef, A. Effect of Degree of Hydrolysis and Protease Type on the Antioxidant Activity of Protein Hydrolysates from Cuttlefish (Sepia officinalis) By-Products. J. Aquat. Food Prod. Technol. 2013, 22, 436-448. [CrossRef]

120. Lassoued, I.; Mora, L.; Nasri, R.; Jridi, M.; Toldrá, F.; Aristoy, M.-C.; Barkia, A.; Nasri, M. Characterization and comparative assessment of antioxidant and ACE inhibitory activities of thornback ray gelatin hydrolysates. J. Funct. Foods 2015, 13, 225-238. [CrossRef]

121. Lee, J.K.; Jeon, J.-K.; Byun, H.-G. Antihypertensive effect of novel angiotensin I converting enzyme inhibitory peptide from chum salmon (Oncorhynchus keta) skin in spontaneously hypertensive rats. J. Funct. Foods 2014, 7, 381-389. [CrossRef]

122. Leone, A.; Lecci, R.M.; Durante, M.; Meli, F.; Piraino, S. The Bright Side of Gelatinous Blooms: Nutraceutical Value and Antioxidant Properties of Three Mediterranean Jellyfish (Scyphozoa). Mar. Drugs 2015, 13, 4654-4681. [CrossRef]

123. Zhang, Q.; Song, C.; Zhao, J.; Shi, X.; Sun, M.; Liu, J.; Fu, Y.; Jin, W.; Zhu, B. Separation and Characterization of Antioxidative and Angiotensin Converting Enzyme Inhibitory Peptide from Jellyfish Gonad Hydrolysate. Molecules 2018, 23, 94. [CrossRef] [PubMed]

124. Zhuang, Y.L.; Sun, L.P.; Zhao, X.; Hou, H.; Li, B.F. Investigation of gelatin polypeptides of jellyfish (Rhopilema esculentum) for their antioxidant activity in vitro. Food Technol. Biotechnol. 2010, 48, 222-228.

125. Admassu, H.; Gasmalla, M.A.A.; Yang, R.; Zhao, W. Identification of Bioactive Peptides with $\alpha$-Amylase Inhibitory Potential from Enzymatic Protein Hydrolysates of Red Seaweed (Porphyra spp.). J. Agric. Food Chem. 2018, 66, 4872-4882. [CrossRef]

126. Indumathi, P.; Mehta, A. A novel anticoagulant peptide from the Nori hydrolysate. J. Funct. Foods 2016, 20, 606-617. [CrossRef]

127. Cullis, P.R.; Kruijff, B. Lipid polymorphism and the functional roles of lipids in biological membranes. Biochim. Biophys. Acta Rev. Biomembr. 1979, 559, 399-420. [CrossRef]

128. Adamovich, Y.; Aviram, R.; Asher, G. The emerging roles of lipids in circadian control. Biochim. Biophys. Acta Mol. Cell Biol. Lipids 2015, 1851, 1017-1025. [CrossRef]

129. Mišurcová, L.; Ambrožová, J.; Samek, D. Seaweed Lipids as Nutraceuticals. Adv. Food Nutr. Res. 2011, 64, 339-355. [CrossRef] [PubMed]

130. Calder, P. Very long-chain n-3 fatty acids and human health: Fact, fiction and the future. Proc. Nutr. Soc. 2018, 77, 52-72. [CrossRef]

131. Li, X.; Bi, X.; Wang, S.; Zhang, Z.; Li, F.; Zhao, A.Z. Therapeutic Potential of $\omega-3$ Polyunsaturated Fatty Acids in Human Autoimmune Diseases. Front. Immunol. 2019, 10, 2241. [CrossRef]

132. Chotard, É.; Mohammadi, F.; Julien, P.; Berthiaume, L.; Rudkowska, I.; Bertrand, N. Drinkable lecithin nanovesicles to study the biological effects of individual hydrophobic macronutrients and food preferences. Food Chem. 2020, 322, 126736. [CrossRef]

133. Higgins, J.P.; Flicker, L. Lecithin for dementia and cognitive impairment. Cochrane Database Syst. Rev. 2000, CD001015. [CrossRef]

134. Baker, C. Lecithin in cosmetics. In Lecithin: Sources, Manufacture E Uses; Szuhaj, B.F., Ed.; American Oil Chemists' Society: Champaign, IL, USA, 1989; pp. 253-260.

135. Uddin, M.S.; Ahn, H.-M.; Kishimura, H.; Chun, B.-S. Production of valued materials from squid viscera by subcritical water hydrolysis. J. Environ. Biol. 2010, 31, 675-679. [PubMed]

136. Uddin, S.; Kishimura, H.; Chun, B.-S. Isolation and Characterization of Lecithin from Squid (Todarodes pacificus) Viscera Deoiled by Supercritical Carbon Dioxide Extraction. J. Food Sci. 2011, 76, C350-C354. [CrossRef] [PubMed]

137. Cho, S.-Y.; Joo, D.-S.; Choi, H.-G.; Nara, E.; Miyashita, K. Oxidative stability of lipids from squid tissues. Fish. Sci. 2001, 67, 738-743. [CrossRef]

138. Nguyen, T.T.; Zhang, W.; Barber, A.R.; Su, P.; He, S. Significant Enrichment of Polyunsaturated Fatty Acids (PUFAs) in the Lipids Extracted by Supercritical CO2from the Livers of Australian Rock Lobsters (Jasus edwardsii). J. Agric. Food Chem. 2015, 63, 4621-4628. [CrossRef] [PubMed] 
139. Amiguet, V.T.; Kramp, K.L.; Mao, J.; McRae, C.; Goulah, A.; Kimpe, L.E.; Blais, J.; Arnason, J.T. Supercritical carbon dioxide extraction of polyunsaturated fatty acids from Northern shrimp (Pandalus borealis Kreyer) processing by-products. Food Chem. 2012, 130, 853-858. [CrossRef]

140. Sahena, F.; Zaidul, I.; Jinap, S.; Jahurul, M.; Khatib, A.; Norulaini, N. Extraction of fish oil from the skin of Indian mackerel using supercritical fluids. J. Food Eng. 2010, 99, 63-69. [CrossRef]

141. Ferdosh, S.; Sarker, Z.I.; Ab Rahman, N.N.N.; Akanda, J.H.; Ghafoor, K.; Ab Kadir, M.O. Simultaneous Extraction and Fractionation of Fish Oil from Tuna By-Product Using Supercritical Carbon Dioxide (SC-CO2). J. Aquat. Food Prod. Technol. 2014, 25, 230-239. [CrossRef]

142. Haq, M.; Ahmed, R.; Cho, Y.-J.; Chun, B.-S. Quality Properties and Bio-potentiality of Edible Oils from Atlantic Salmon Byproducts Extracted by Supercritial Carbon Dioxide and Conventional Methods. Waste Biomass Valorization 2016, 8, $1953-1967$. [CrossRef]

143. Bierer, T.L.; Bui, L.M. Improvement of Arthritic Signs in Dogs Fed Green-Lipped Mussel (Perna canaliculus). J. Nutr. 2002, 132, 1634S-1636S. [CrossRef] [PubMed]

144. Whitehouse, M.W.; Macrides, T.A.; Kalafatis, N.; Betts, W.H.; Haynes, D.R.; Broadbent, J. Anti-inflammatory activity of a lipid fraction (lyprinol) from the NZ green-lipped mussel. Inflammopharmacology 1997, 5, 237-246. [CrossRef] [PubMed]

145. Reddy, L.H.; Couvreur, P. Squalene: A natural triterpene for use in disease management and therapy. Adv. Drug Deliv. Rev. 2009, 61, 1412-1426. [CrossRef]

146. Huang, Z.-R.; Lin, Y.-K.; Fang, J.-Y. Biological and Pharmacological Activities of Squalene and Related Compounds: Potential Uses in Cosmetic Dermatology. Molecules 2009, 14, 540-554. [CrossRef]

147. Kim, S.-K.; Karadeniz, F. Biological Importance and Applications of Squalene and Squalane. In Advances in Food and Nutrition Research; Elsevier BV: Amsterdam, The Netherlands, 2012; Volume 65, pp. 223-233.

148. Burton, G.W.; Ingold, K.U. Autoxidation of biological molecules. Antioxidant activity of vitamin E and related chain-breaking phenolic antioxidants in vitro. J. Am. Chem. Soc. 1981, 103, 6472-6477. [CrossRef]

149. Fujisawa, A.; Dunlap, W.C.; Yamamoto, Y. Vitamin E protection in the biochemical adaptation of marine organisms to cold-water environments. Comp. Biochem. Physiol. Part B Biochem. Mol. Biol. 2010, 157, 145-158. [CrossRef]

150. Seabra, L.M.J.; Pedrosa, L.F.C. Astaxanthin: Structural and functional aspects. Rev. Nutr. 2010, 23, 1041-1050. [CrossRef]

151. Armenta-Lopez, R.; Guerrero, I.L.; Huerta, S. Astaxanthin Extraction from Shrimp Waste by Lactic Fermentation and Enzymatic Hydrolysis of the Carotenoprotein Complex. J. Food Sci. 2002, 67, 1002-1006. [CrossRef]

152. Sachindra, N.; Mahendrakar, N. Process optimization for extraction of carotenoids from shrimp waste with vegetable oils. Bioresour. Technol. 2005, 96, 1195-1200. [CrossRef]

153. Eggersdorfer, M.; Wyss, A. Carotenoids in human nutrition and health. Arch. Biochem. Biophys. 2018, 652, 18-26. [CrossRef] [PubMed]

154. Rao, A.V.; Rao, L.G. Carotenoids and human health. Pharmacol. Res. 2007, 55, 207-216. [CrossRef]

155. Bohn, T. Carotenoids, Chronic Disease Prevention and Dietary Recommendations. Int. J. Vitam. Nutr. Res. 2017, 87, 121-130. [CrossRef] [PubMed]

156. Kurihara, H.; Koda, H.; Asami, S.; Kiso, Y.; Tanaka, T. Contribution of the antioxidative property of astaxanthin to its protective effect on the promotion of cancer metastasis in mice treated with restraint stress. Life Sci. 2002, 70, 2509-2520. [CrossRef]

157. Sila, A.; Ayed-Ajmi, Y.; Sayari, N.; Nasri, M.; Martinez-Alvarez, O.; Bougatef, A. Antioxidant and Anti-proliferative Activities of Astaxanthin Extracted from the Shell Waste of Deep-water Pink Shrimp (Parapenaeus longirostris). Nat. Prod. J. 2013, 3, 82-89. [CrossRef]

158. Taksima, T.; Limpawattana, M.; Klaypradit, W. Astaxanthin encapsulated in beads using ultrasonic atomizer and application in yogurt as evaluated by consumer sensory profile. LWT 2015, 62, 431-437. [CrossRef]

159. Neori, A.; Chopin, T.; Troell, M.; Buschmann, A.H.; Kraemer, G.P.; Halling, C.; Shpigel, M.; Yarish, C. Integrated aquaculture: Rationale, evolution and state of the art emphasizing seaweed biofiltration in modern mariculture. Aquaculture 2004, 231, 361-391. [CrossRef]

160. Fung, A.; Hamid, N.; Lu, J. Fucoxanthin content and antioxidant properties of Undaria pinnatifida. Food Chem. 2013, 136, 1055-1062. [CrossRef]

161. Raji, V.; Loganathan, C.; Sadhasivam, G.; Kandasamy, S.; Poomani, K.; Thayumanavan, P. Purification of fucoxanthin from Sargassum wightii Greville and understanding the inhibition of angiotensin 1-converting enzyme: An in vitro and in silico studies. Int. J. Biol. Macromol. 2020, 148, 696-703. [CrossRef] [PubMed]

162. Rinaudo, M. Chitin and chitosan: Properties and applications. Prog. Polym. Sci. 2006, 31, 603-632. [CrossRef]

163. Jayakumar, R.; Nwe, N.; Tokura, S.; Tamura, H. Sulfated chitin and chitosan as novel biomaterials. Int. J. Biol. Macromol. 2007, 40, 175-181. [CrossRef] [PubMed]

164. Artan, M.; Karadeniz, F.; Karagozlu, M.Z.; Kim, M.-M.; Kim, S.-K. Anti-HIV-1 activity of low molecular weight sulfated chitooligosaccharides. Carbohydr. Res. 2010, 345, 656-662. [CrossRef] [PubMed]

165. Rúnarsson, Ö.V.; Holappa, J.; Malainer, C.; Steinsson, H.; Hjálmarsdóttir, M.; Nevalainen, T.; Másson, M. Antibacterial activity of N-quaternary chitosan derivatives: Synthesis, characterization and structure activity relationship (SAR) investigations. Eur. Polym. J. 2010, 46, 1251-1267. [CrossRef] 
166. Li, R.; Guo, Z.; Jiang, P. Synthesis, characterization, and antifungal activity of novel quaternary chitosan derivatives. Carbohydr. Res. 2010, 345, 1896-1900. [CrossRef]

167. Wang, S.-L.; Liang, T.-W.; Yen, Y.-H. Bioconversion of chitin-containing wastes for the production of enzymes and bioactive materials. Carbohydr. Polym. 2011, 84, 732-742. [CrossRef]

168. Apetroaei, M.R.; Zgârian, R.G.; Manea, A.-M.; Rau, I.; Tihan, G.T.; Schroder, V. New source of chitosan from Black Sea marine organisms identification. Mol. Cryst. Liq. Cryst. 2016, 628, 102-109. [CrossRef]

169. Takarina, N.D.; Fanani, A.A. Characterization of chitin and chitosan synthesized from red snapper (Lutjanus sp.) scale's waste. In Proceedings of the 2nd International Symposium on Current Progress in Mathematics and Sciences, Bali, Indonesia, 1-2 November 2016. [CrossRef]

170. Rasti, H.; Parivar, K.; Baharara, J.; Iranshahi, M.; Namvar, F. Chitin from the Mollusc Chiton: Extraction, Characterization and Chitosan Preparation. Iran. J. Pharm. Res. 2017, 16, 366-379.

171. Jothi, N.; Nachiyar, R.K. Identification and isolation of chitin and chitosan from cuttle bone of Sepia prashadi Winckworth, Glob. J. Biotechnol. Biochem. 2013, 8, 1-7. [CrossRef]

172. Alencar, P.O.C.; Lima, G.C.; Barros, F.C.N.; Costa, L.E.; Ribeiro, C.V.P.; Sousa, W.M.; Sombra, V.G.; Abreu, C.M.W.; Abreu, E.S.; Pontes, E.O.; et al. A novel antioxidant sulfated polysaccharide from the algae Gracilaria caudata: In vitro and in vivo activities. Food Hydrocoll. 2019, 90, 28-34. [CrossRef]

173. Sudharsan, S.; Subhapradha, N.; Seedevi, P.; Shanmugam, V.; Madeswaran, P.; Shanmugam, A.; Srinivasan, A. Antioxidant and anticoagulant activity of sulfated polysaccharide from Gracilaria debilis (Forsskal). Int. J. Biol. Macromol. 2015, 81, 1031-1038. [CrossRef]

174. Zainudin, N.H.; Sirajudeen, K.N.S.; Ghazali, F.C. Marine sourced glycosaminoglycans "GAGs". J. Adv. Lab. Res. Biol. 2014, 5, 46-53.

175. Valcarcel, J.; Novoa-Carballal, R.; Perez-Martin, R.; Reis, R.L.; Vázquez, J.A. Glycosaminoglycans from marine sources as therapeutic agents. Biotechnol. Adv. 2017, 35, 711-725. [CrossRef]

176. Mycroft-West, C.; Yates, E.A.; Skidmore, M.A. Marine glycosaminoglycan-like carbohydrates as potential drug candidates for infectious disease. Biochem. Soc. Trans. 2018, 46, 919-929. [CrossRef]

177. Colliec-Jouault, S.; Zykwinska, A. Marine glycosaminoglycans (GAGs) and GAG-mimetics: Applications in medicine and tissue engineering. In Extracellular Sugar-Based Biopolymers Matrices; Cohen, E., Merzendorfer, H., Eds.; Springer: Cham, Switzerland, 2019; pp. 625-648.

178. Cheras, P.; Stevenson, L.; Myers, S. Vascular mechanisms in osteoarthritis: Rationale for treatment with a marine-based complementary medicine. Osteoarthr. Cartil. 2005, 13, S95.

179. Aroma New Zealand Ltd. Available online: www.aromanz.com (accessed on 31 March 2021).

180. Draget, K.I. Alginates. In Handbook of Hydrocolloids, 2nd ed.; Phillips, G.O., Williams, P., Eds.; Woodhead Publishing: Shaxton, UK, 2009; pp. 807-828, ISBN 9781845695873.

181. Borazjani, N.J.; Tabarsa, M.; You, S.; Rezaei, M. Effects of extraction methods on molecular characteristics, antioxidant properties and immunomodulation of alginates from Sargassum angustifolium. Int. J. Biol. Macromol. 2017, 101, 703-711. [CrossRef]

182. Marudhupandi, T.; Kumar, T.T.A.; Lakshmanasenthil, S.; Suja, G.; Vinothkumar, T. In vitro anticancer activity of fucoidan from Turbinaria conoides against A549 cell lines. Int. J. Biol. Macromol. 2015, 72, 919-923. [CrossRef]

183. Vo, T.-S.; Kim, S.-K. Fucoidans as a natural bioactive ingredient for functional foods. J. Funct. Foods 2013, 5, 16-27. [CrossRef]

184. Palanisamy, S.; Vinosha, M.; Marudhupandi, T.; Rajasekar, P.; Prabhu, N.M. Isolation of fucoidan from Sargassum polycystum brown algae: Structural characterization, in vitro antioxidant and anticancer activity. Int. J. Biol. Macromol. 2017, 102, 405-412. [CrossRef]

185. Kumar, T.V.; Lakshmanasenthil, S.; Geetharamani, D.; Marudhupandi, T.; Suja, G.; Suganya, P. Fucoidan-A $\alpha$-d-glucosidase inhibitor from Sargassum wightii with relevance to type 2 diabetes mellitus therapy. Int. J. Biol. Macromol. 2015, 72, 1044-1047. [CrossRef]

186. Del Rio, D.; Rodriguez-Mateos, A.; Spencer, J.P.E.; Tognolini, M.; Borges, G.; Crozier, A. Dietary (Poly)phenolics in Human Health: Structures, Bioavailability, and Evidence of Protective Effects Against Chronic Diseases. Antioxid. Redox Signal. 2013, 18, 1818-1892. [CrossRef]

187. Zaharudin, N.; Salmeán, A.A.; Dragsted, L.O. Inhibitory effects of edible seaweeds, polyphenolics and alginates on the activities of porcine pancreatic $\alpha$-amylase. Food Chem. 2018, 245, 1196-1203. [CrossRef]

188. Jesumani, V.; Du, H.; Pei, P.; Aslam, M.; Huang, N. Comparative study on skin protection activity of polyphenol-rich extract and polysaccharide-rich extract from Sargassum vachellianum. PLoS ONE 2020, 15, e0227308. [CrossRef]

189. Yoon, M.; Kim, J.-S.; Seo, S.; Lee, K.; Um, M.Y.; Lee, J.; Jung, J.; Cho, S. Dieckol, a Major Marine Polyphenol, Enhances Non-Rapid Eye Movement Sleep in Mice via the GABAA-Benzodiazepine Receptor. Front. Pharmacol. 2020, 11, 1-10. [CrossRef]

190. Mai, H.; Fotedar, R.; Fewtrell, J. Evaluation of Sargassum sp. as a nutrient-sink in an integrated seaweed-prawn (ISP) culture system. Aquaculture 2010, 310, 91-98. [CrossRef]

191. Daniotti, S.; Re, I. Marine Biotechnology: Challenges and Development Market Trends for the Enhancement of Biotic Resources in Industrial Pharmaceutical and Food Applications. A Statistical Analysis of Scientific Literature and Business Models. Mar. Drugs 2021, 19, 61. [CrossRef] 
192. Venugopal, V. Nutrients and nutraceuticals from seafood. In Bioactive Molecules in Food; Mérillon, J.M., Ramawat, K.G., Eds.; Springer International Publishing: New York, NY, USA, 2018; pp. 1-45.

193. Liu, D.; Nikoo, M.; Boran, G.; Zhou, P.; Regenstein, J.M. Collagen and Gelatin. Annu. Rev. Food Sci. Technol. 2015, 6, 527-557. [CrossRef]

194. Adam, O.; Beringer, C.; Kless, T.; Lemmen, C.; Adam, A.; Wiseman, M.; Adam, P.; Klimmek, R.; Forth, W. Anti-inflammatory effects of a low arachidonic acid diet and fish oil in patients with rheumatoid arthritis. Rheumatol. Int. 2003, 23, 27-36. [CrossRef]

195. Grienke, U.; Silke, J.; Tasdemir, D. Bioactive compounds from marine mussels and their effects on human health. Food Chem. 2014, 142, 48-60. [CrossRef]

196. Cheung, R.C.F.; Ng, T.B.; Wong, J.H. Marine Peptides: Bioactivities and Applications. Mar. Drugs 2015, 13, 4006-4043. [CrossRef] [PubMed]

197. Kushnarev, M.; Pirvulescu, I.P.; Candido, K.D.; Knezevic, N.N. Neuropathic pain: Preclinical and early clinical progress with voltage-gated sodium channel blockers. Expert Opin. Investig. Drugs 2020, 29, 259-271. [CrossRef] [PubMed] 